Document downloaded from:

http://hdl.handle.net/10251/148098

This paper must be cited as:

Molero Prieto, GD.; Santarremigia Rosaleny, FE.; Aragonés-Beltrán, P.; Pastor-Ferrando, J. (2017). Total safety by design: Increased safety and operability of supply chain of inland terminals for containers with dangerous goods. Safety Science. 100(B):168-182. https://doi.org/10.1016/j.ssci.2016.10.007

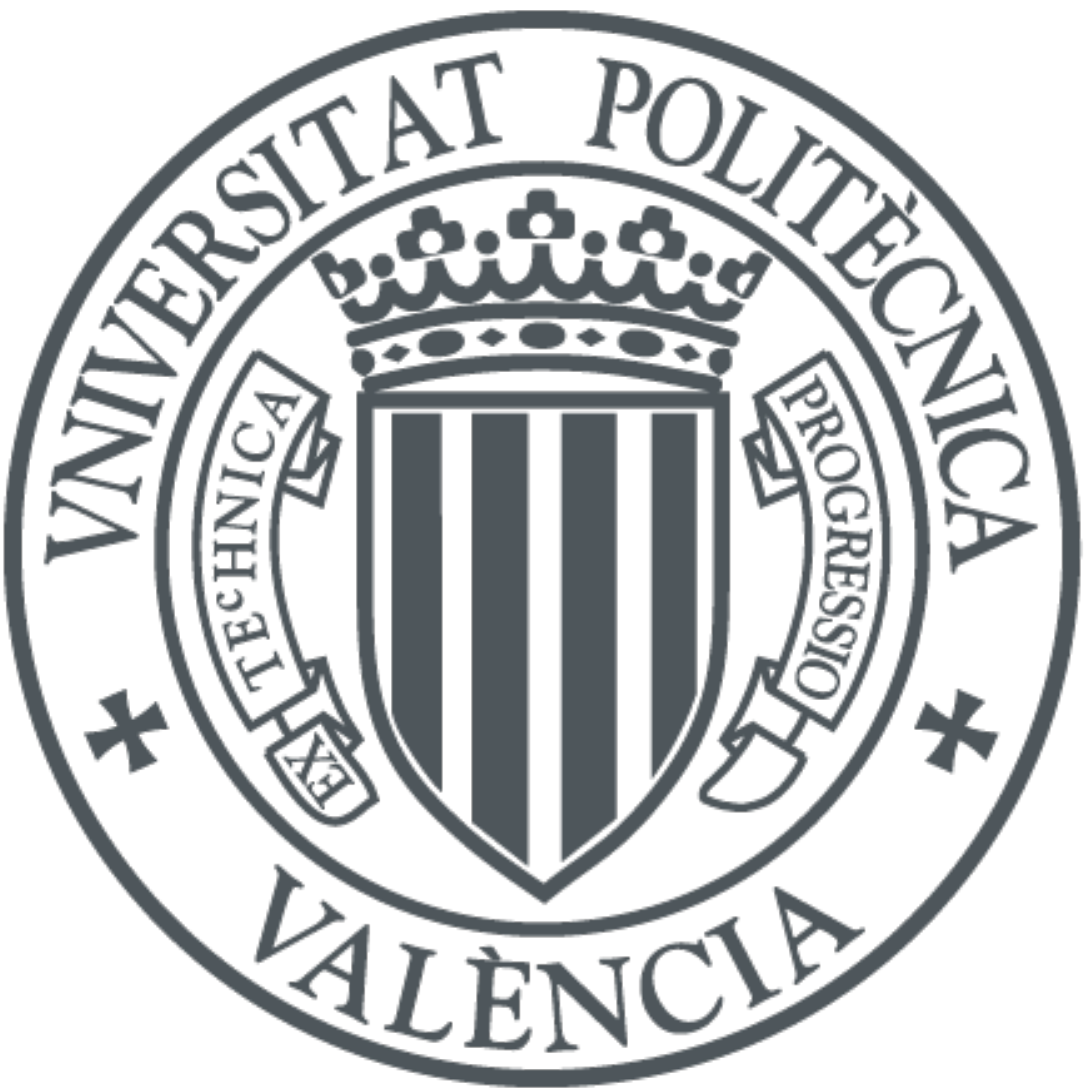

The final publication is available at

https://doi.org/10.1016/j.ssci.2016.10.007

Copyright Elsevier

Additional Information 
Total safety by Design: increased safety and operability of supply chain of inland terminals for containers with dangerous goods

\section{Authors and affiliation}

Molero, Gemma Doloresa; Santarremigia, Francisco Enriquea; Aragones-Beltrán, Pablo ${ }^{\mathrm{b}}$; PastorFerrando, Juan-Pascual ${ }^{b}$.

\section{Affiliation:}

a) AITEC Parque Tecnológico. C/ Charles Robert Darwin, 20. 46980 Paterna - VALENCIA SPAIN. Phone (+34) 9613669 69. Dpt. de Proyectos de I+D+i

b) UNIVERSITAT POLITĖCNICA DE VALĖNCIA. Camino de Vera, s/n. 46022 VALENCIA SPAIN, Phone: (+34) 9638770 00. Dpt. de Proyectos de Ingeniería.

\section{Corresponding author:}

Molero, Gemma Dolores (gmolero@aitec-intl.com) 


\title{
Total Safety by Design: increased safety and operability of supply chain of inland terminals for containers with dangerous goods
}

\section{Highlights}

- Disaster prevention from the earliest stages of inland terminals for dangerous goods (ITDGs) design.

- Holistic analysis of the criteria involved in the design of safe ITDGs.

- Diminishment of safety risks associated with ITDGs into a total performance management (safety, environmental and productivity).

- Assessment tool for the total safety management of ITDGs.

- Improving the social inclusivity of seaports by using the ITDG concept as a safe option.

\begin{abstract}
In recent years, there has been a considerable increase in the international transport of containers with dangerous goods, increasing the risk of seaports and surrounding cities together with the introduction of inherent environmental and security disaster risks. Therefore, there is an increasing interest in seaports that are more socially inclusive, addressing the storage of containers of hazardous goods to safe inland terminals. An appropriate design of inland terminals for containers with dangerous goods (ITDGs) may contribute to the achievement of a sustainable development and the minimization of risks, avoiding disasters such as Tianjin. The objective of this study was the analysis of the criteria used for the design of safe, secure, cost efficient and greener ITDGs by applying the multicriteria decision theory AHP (Analitic hierarchic process). Criteria regarding safety and security, environmental care, productivity and information and communication technologies (ICT) have been considered simultaneously into a total performance management system.
\end{abstract}




\section{Keywords}

Disaster prevention; Inland terminal; dangerous goods; supply chain; multicriteria decision; total safety management

\section{Introduction}

Inland terminals for containers with dangerous goods (ITDGs) are suggested to resolve some of the current drawbacks related to seaport or river port facilities in a seamless supply chain. The social vulnerability of the surrounding areas involves the "physical" impact of an event where people are located and the ability for key institutions to respond and manage the event effectively to cause minimal disruption to exposed communities (Nogal et al., 2016). Vulnerability is related to the sensible geographic location of these facilities with respect to environmental, safety and security risks (Ambrosino and Sciomachen, 2012). The use of ITDGs as multimodal facilities allows seaport social inclusion in cities, making them safer facilities. Moreover, traffic jams and congestion in cities due to port activities may be relieved to some extent.

The sales of chemical products produced in the European market from 2003 to 2013 increased from 1,326 trillion euros to 3,156 trillion euros (CEFIC, 2015). As a consequence, statistics indicate that the traffic of dangerous goods transported in containers is increasing to record levels by the different methods of transport (road, railway, maritime transport over short distances and inland waterway transport). Dangerous goods are products such as materials, including bulk substances and packed ones, that have the properties indicated in the IMDG code (IMDG 37-14) or ADR code (UNECE, 2015), as well as any other substance that may constitute a threat to the security in the port area or its vicinity and require special treatment. Thus, the storage requirements of dangerous goods at seaports should consider not only the safety and environmental issues but also the high social impact. The increasing demands of the decongestion of the seaports and the cities where they are located (Wiegmans and Louw, 2011) require innovation and studies of the technologies and processes involved in the supply chain of 
containers with dangerous goods. The development of seaport-dry port dyads plays a key role (Bask et al., 2014), and the promotion of intermodal freight transport through dry ports has attracted increasing interest (Hanaoka and Regmi, 2011; Clott and Hartman, 2016), giving room to the port regionalization concept (Monios and Wilmsmeier, 2012).

Unfortunately, the risks associated with hazardous materials have not been completely avoided by means of intermodal dry port solutions. Those risks are associated with drayage to a significant extent, and current research lines address this topic (Romero et al., 2016). These efforts are also reflected in European policies (MT, 2015) committing to the development of solutions for sustainable transport and trying to reduce the road transport of those goods by means of synchromodal transport (Zhang and Pel 2016). In a complementary way, the risks associated with ITDGs should also be minimised, achieving infrastructures and networks more resilient to extreme events (Axelsen et al., 2016; Zhang et al., 2015), consequences of climate change (EEA, 2014), terrorist attacks (Argenti et al., 2015) or accidents as Tianjin (Huang and Zhang, 2015). For instance, 1,400 sudden leakage accidents occurred in China from 2006 to 2011 in dangerous goods handling and storage facilities ( $\mathrm{Li}$ et al., 2014). 13\% of the major fire accidents that occurred in the USA also happened in storage facilities (Badger, 2010). In the context of infrastructure systems, resilience can be defined as a function of the vulnerability of the system to potential disruption and its adaptive capacity in recovering to an acceptable level of service within a reasonable timeframe after being affected by disruption (Mansouri et al., 2010). Therefore, it is essential to integrate the vulnerability to extreme weather events and accidents into the decision making process involved in the design of logistically efficient multimodal facilities through identifying, analysing and prioritizing adaptation options (FHWA, 2012). On the other hand, as Lu and Yang reported (2010), greater safety leadership will lead to good safety behaviour and further reduce accident occurrences.

The design of ITDGs is a complex problem that must consider a variety of factors (Beresford et al, 2012) such as safety, protection against intruders, environmental concerns, equipment performance, costs, business intelligence $(\mathrm{BI})$ and information and communications technology (ICT), while managers seek to achieve more inclusive terminals with less noise, lower 
emissions and lower risks during the process of management. We can find in the literature some publications focused on decision making methods for inland terminals, although the problem has thus far not been addressed comprehensively. There are papers considering the geographic location of an inland terminal (Portugal et al., 2011), the container-handling equipment (CHE) (Gambardella et al., 2001); plant distributions (Kim and Kim, 2002); the collection of follow-up information to prevent thefts of commodities (Tsai, 2006); reductions in the consumption of energy (He et al., 2015) and regarding procedures for the concession of port terminals to private operators (Monios and Bergqvist, 2015). Despite these pioneering works, the study of inland terminals still remains underdeveloped, at least in comparison with that on seaports. This can easily be verified in scientific databases of peer-reviewed scientific literature (Scopus, 2016).

Thus, there is a need to consider the problem of terminal design from a global point of view, especially for ITDGs. This paper focuses as a novelty on criteria to be considered in the design and management of safe ITDGs from a global point of view, taking in consideration the hazards inherent to dangerous goods. Consequently, the main aim of this investigation is to describe these relevant criteria and to prioritize them using the multicriteria decision theory. This purpose is aligned with the European policy that promotes methods of re-design and reengineering adapted to new needs and ensures greater efficiency. The methods of design and innovative construction must be environmentally friendly, flexible and with low maintenance costs $(E C, 2016)$. Research should try to address the emerging challenges of society. In that sense, we have considered criteria such as equipment reliability, flood risk, preventive measures and emergency response procedures that are directly aimed to achieve safer, greener and more efficient inland terminals for containers with dangerous goods (ITDGs).

\subsection{Analytic hierarchy process (AHP)}

To achieve the main purpose of our research, it is necessary to apply a suitable technique for the structuration and organization of the design procedures from the earliest stages of the project (Aragonés-Betltrán, et al. 2014). Although we assume according to Bask et al. (2014) that there 
is no dry port solution that suits all needs, we take on the challenge of achieving a commitment situation that satisfies multiple requirements in a holistic way. The application of models based in cost-benefit analyses (CBA) for decision making processes for transport facilities could sometimes hinder the application of sustainable solutions (Flämig and Hesse, 2011) and criteria that may be introduced on the basis of multicriteria analysis (Cullinane et al. 2006; Palacio et al., 2016). Multi-Criteria Decision Analysis (MCDA) and Multicriteria Decision Making (MCDM) methods are especially useful techniques when several criteria ought to be considered to achieve a goal. The common aim of the diverse available techniques is to be able to evaluate and choose between alternatives based on a systematic analysis considering the limitations observed in group work decisions. The distinct methods vary in the method of evaluation of the criteria and the combination of results necessary to attain a general evaluation. Some techniques establish a ranking of criteria, others identify the best alternative, and others differentiate between acceptable and unacceptable alternatives (Linkov and Ramadan, 2004; Vaidya and Kumar 2006). Specifically, we addressed the problem by applying the analytic hierarchy process (AHP) tool for decision making, proposed by Saaty for the first time in 1980 but continually updated (Saaty, 1980; 2013; 2016). One of the concrete advantages of the method is that it allows a criteria prioritisation, even for subjective criteria. In fact, rather than producing a precise decision, the AHP helps decision-makers find the solution that best fits their objective and their knowledge. AHP instruments provide a structured analysis for the design of ITDGs that allows establishing a hierarchy of criteria that can be scientifically contrasted by means of a rigorous mathematical procedure. The method organizes a hierarchy in a tree diagram, where the main goal is decomposed into criteria organized on different levels. The AHP method received some criticisms in its early stages (Holguín-Veras, 1995), mainly related to the theoretical foundation of the method or the possibility of the method suffering from rank reversal, but the main criticisms were overcome, and the AHP method is now widely accepted and applied by governmental agencies, corporations and consulting firms (Al-Harbi, 2001).

Tramarico et al. (2015) made a bibliometric study of the utilisation of multicriteria methods applied to the supply chain management. The authors showed that the most used MCDA method 
in the publications from 2011 to 2014 was the AHP method, with 1,872 articles, followed by the ELECTRE method, with 201 articles, and MAUT, with 61. Wider studies such as that of Wallenius et al. (2008) also enhance the use of the AHP method.

\subsection{State of the art}

AHP methods have been successfully used in comparative studies between different available ports considering the criteria of services in ports, services in the terminals of containers, economic factors and geographic location (Teng et al., 2004; Yeo et al., 2008). Yang et al. (2014) used the AHP method to prioritise the criteria of sustainability, establishing a comparison between several Asian ports and noting that transport companies and seaport managers have different perceptions of the criteria of sustainability.

Multicriteria tools that have been applied to the design of terminals of containers have mainly been focused on the improvement of the performance (Bruzzone and Signorile, 1998; Seyedalizadeh et al., 2009) and to determine the optimum number of automated guided vehicles in each terminal (Liu et al. 2002). AHP has also been used to prioritise the factors that influence the equipment conveyors of containers in the port terminals (Peilin et al., 2012; Yang et al., 2014). The authors concluded that the most important criteria to consider are the simplification of the procedures, the lease of the terminals, the time of transfer, systems of favourable port taxes and the efficiency of the operations in the terminal. Awad-Núñez et al. (2015) proposed a methodology using Bayesian networks and multi-criteria decision analysis to measure the sustainability of the geographic locations of dry ports. The authors found that the most important variables were those related to environmental protection.

Huang et al. (2003) studied the usage of containers in ports by means of a SWOT analysis (Strengths, Weaknesses, Opportunities and Threats), establishing criteria related to the quality of performance, efficiency, cost, equipment quantity, capacity and geographic location. AHP has also been applied to make improvements in the layout of a terminal of containers (Golbabaie et 
al., 2012). The authors considered three different types of layout design whose planning would affect the productivity and success of the projects. The performance indicators considered were the fixed and variable costs, time of transfer, flexibility and drift possibilities. A recent work applied the AHP model to decision making processes involving the transport of dangerous goods, considering criteria of safety and the environment (Ocalir-Akunal, 2016).

Publications considering important factors involved in the handling of dangerous goods in terminals such as safety, security and the environment are scarce. Among them, Assadipour et al. (2015) dealt with the ITDG congestion risk as a significant portion of the network risk. The authors postulated that the accumulation of hazmat containers would increase the potential for incidents in the surrounding areas. They propose the application of a customized solution methodology that makes use of a non-dominating sorting genetic algorithm to achieve shorter waiting times and tighter delivery times in the facilities.

The majority of the publications try to solve partial problems or review some particular cases of terminals in inland ports already established, but there has been an evolution towards considering the problem from a more global point of view (Bernechea and Arnaldos-Viger, 2013). Safety management programs do not always improve the results of safety as expected if they are mostly focused on the technical requirements and on obtaining short-term results (Zhi et al., 2012). Total Safety Management should involve the total organization in establishing and maintaining a safe and a healthful work environment integrating all aspects of safety construction (intention, behaviour, culture and processes, environmental concerns, etc.) to achieve a safe work environment, that is consistent with peak performance and continuous improvement (Agwu, 2012). Therefore, other areas of interest of the company should also be taken into consideration. Within these areas we should include the area of equipment performance, which is directly related to the economic efficiency of the company. In general, costs related to security investment are well known to each particular company, although other non-financial benefits related to the prevention of accidents that cannot be easily measurable.

Managerial decision-making is also driven by factors other than rational management accounting in such an emotional sensitive topic as safety, when the question is about human 
lives. Aligning the safety perspective and business strategy provides value for organisations when they make interventions and investments. They should be stated as a shared goal instead of many varied or even conflicting goals (Tappura et al., 2015) that may include business intelligence considerations. All of the operative knowledge, such as procedures, technical manuals and best-practices concerning prevention and reduction of workplace accidents, should be a mandatory part of the material available to workers in dangerous and risky areas and must be shared through business intelligence tools (Armería and De La Fuente, 2015). In this sense, the use of ICT facilitates collaboration and information exchange among the scattered members of a project. In safety and progress monitoring and tracking technologies play a key role in the management of these important tasks (Martínez-Rojas et. al, 2016). On the other hand, the area of environmental management of the company should also be considered, not only because of its intrinsic importance, but by its direct relation to the management of global security. Certain events or circumstances considered in the area of environmental management not only have an effect on the surrounding natural area to ITDG, but also to the direct security of the workers themselves. For example, the risk of flooding in the installation, the acoustic impact, the existence of a proper sewerage network maintenance and staff properly trained to avoid and manage emergency situations impinges on global security situations within the facility. In other

research areas, AHP method have been successfully used with holistic approaches (DelgadoGaván, 2014; Harik et al., 2015; Lee, 2015), as the proposed in this paper, showing a growing trend to apply the method.

\section{Methods}

The process followed in this research started with an analysis stage, including the problem formulation and the establishment of criteria involved in the decision-making process (Molero, 2016) (Fig. 1). To prioritise the criteria involved in the design of ITDGs, an expertise board was configured, constituted by professional experts with wide technical experience and recognized 
prestige in their areas. Within this panel of experts, the model development and the identification of criteria were carried out in a synthesis stage. To do this, several work session meetings were held during the investigation period. In those meetings, literature information analyses and the knowledge of the experts provided profitable tools, working by consensus, for the criteria selection. These experts also participated in the preparation of the hierarchical model and the prioritisation of the criteria, supported by SuperDecisions software. The process concluded with a final stage of the evaluation and validation of the results obtained.

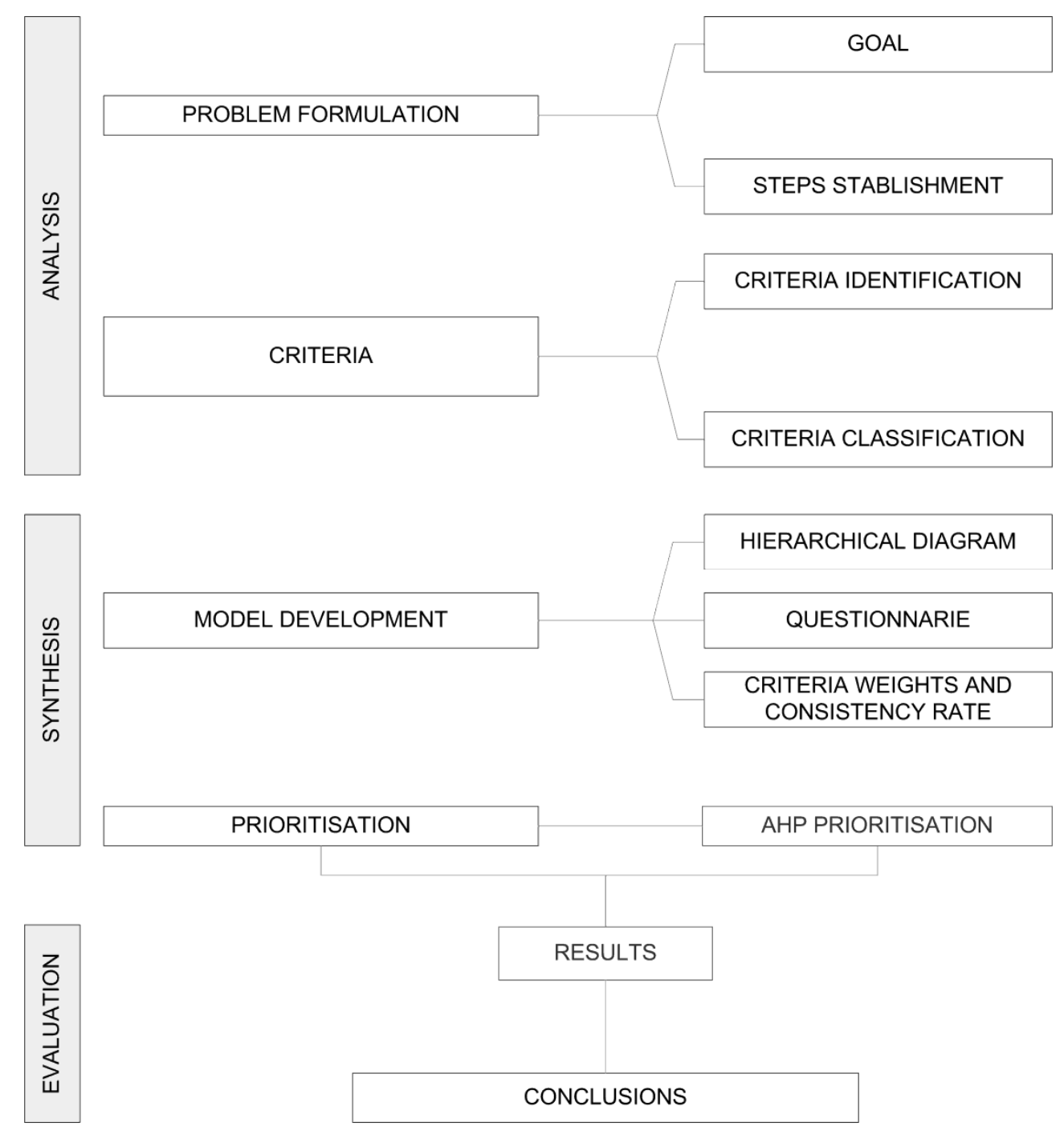

Fig. 1 Working stages diagram.

\subsection{Board expertise definition}


The expertise panel was created according to the Skateholder theory recommendations (Reynolds et al., 2006) involving relevant decision-makers, and was composed of the following professional centres:

Expert 1 is a private centre of technology on the international scene whose main working area is the catchment, promotion, and diffusion of technology for the development of innovation processes in the business sector. This centre is an expert in safety and security and the environment in synchromodal supply chains.

Expert 2 is a company that offers services related to sustainable economic development that encompasses training, consulting and investigation. This expert collaborated in the environmental part of the project based on its experts in resilient facilities and socially inclusive developments.

Expert 3 is a company that is skilled in addressing the needs of the design, assembly and development of different processes and automatisms in the field of industrial production. It has wide experience in the control of network systems on a large scale, as well as in automatisms, machinery, networks of wireless sensors and robotic solutions. This expert participated in the definition and analysis linked to the equipment performance of the ITDGs.

Expert 4 is a non-profit private association that brought valuable ideas related to its experience in the analysis of ICT and $\mathrm{BI}$ in inland transfer terminals based on its wide experience. This expertise was applied in the analysis of the processes and functional and technological requirements of ICT and BI systems.

Expert 5 is a company devoted to the development and commercialization of software in the area of $\mathrm{BI}$, and its specialized areas are ICT and $\mathrm{BI}$.

For a better understanding of ITDGs needs, we proceeded to schedule visits and technical meetings with managers of ITDGs, companies of transport, companies of the import / export of dangerous goods and business associations. In addition, meetings were carried out in several 
scientific forums to share knowledge in international scientific frameworks. (COP21 Paris Climat, 2015; TraConference $2014 ; 2016)$. The working method of interaction with the expert board was based in the DELPHI method (Linstone and Turoff, 1975) for criterion assessment and valuation. This method is based on the analysis of the ideas of a group of skilled experts in a field of knowledge, looking for a consensus of opinions. Each of these companies contributed to the study with two different experienced technicians at different organizational levels (managers, supervisors and operators), providing two independent completed questionnaires.

The expert board defined a hierarchic framework setting three different levels of criteria to implement the AHP method. We worked successively in an iterative manner until arriving at results by consensus by means of repetitiveness and controlled feedback in a work that extended over two years.

\subsection{Criterion prioritisation process}

The board of experts completed surveys of criteria comparisons that resulted in comparison matrices. When more than one member of the panel of experts participated in an area, the distinct opinions of the experts were incorporated by consensus. Each one of the experts has worked with corresponding questionnaires in his/her specialized area. The results of the questionnaires constituted matrices of comparison by means of the scale of Saaty (1980; $2013 ; 2016)$. As functions of the preference of an element shown in a row of the matrix relative to that shown in a column, numeric values are given to the corresponding elements of the matrix: 1.- Similar. Both elements are equally preferred.

3.- Moderate. The element in the row is slightly preferred.

5.- Strong. The element in the row is strongly preferred.

7.- Very strong. The element in the row is very strongly preferred.

9.- Extreme. The element in the row is extremely preferred.

If, on the other hand, the expert prefers the criterion situated in the column, the values to 
assign would be the reciprocals of those previously indicated, i.e., 1/3, 1/5, 1/7 or 1/9.

\section{Results and discussion}

\subsection{Identified criteria}

We established criteria for the design of an ITDG through a thorough study of the state of the art, the relevant laws, and good practices in the environmental, safety and security fields. We had in mind that good working conditions can promote recruiting and retention of skilled workers and the social and economic costs of accidents can be eliminated or reduced (Antao et al., 2016). These criteria were ratified and completed by the expert panel, and then a hierarchic model was proposed (Fig 2). The model establishes a first level of hierarchy corresponding to five main areas: equipment, ICT, $\mathrm{BI}$, safety and security and environment care. Those areas, in turn, include a second level with 21 groups of criteria, and there is also a third hierarchic level containing 88 criteria to be prioritised. Criteria are detailed for all areas in Tables 1, 2, 3, 4 and 5, together with references in the literature to be used for the identification of the criteria of each area. Because each cited paper documents multiple criteria, the literature is summarized globally for the main areas.

In this paper we have identified and weighted the criteria for a better Total Safety Management performance, improving safety management in a global framework, taking into account the efficiency of processes including machinery, and terminal operating systems $(\mathrm{BI}$ and ICT), environmental care and safety and security concerns. With this purpose, the five groups of top-level criteria that influence the goal were identified. In principle the five sets of criteria are not interrelated, but they all affect the fulfilment of the overall objective. Within each group of criteria have been identified second-level groups that include other third-level criteria. Those criteria belonging to the same area are interrelated. In principle, the paper considers a fair influence of each group of criteria on the goal, notwithstanding that could be assigned different weights, 
which would lead to different results.

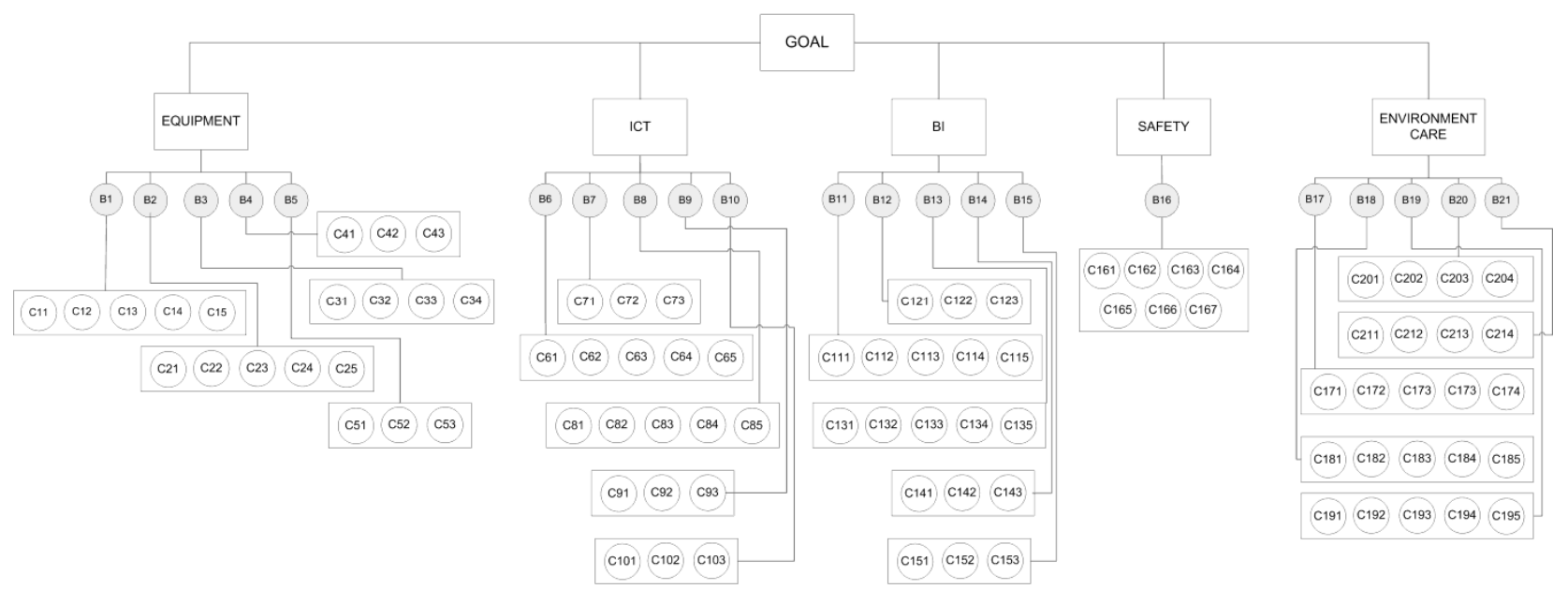

Fig. 2 Proposed hierarchical model.

\begin{tabular}{|c|c|}
\hline \multicolumn{2}{|r|}{ Equipment Area criteria } \\
\hline References & $\begin{array}{l}\text { Gambardella et al. (2001); Kim and Kim (2002); Liu et al. (2002); Teng et al. (2004); Vis et al. } \\
\text { (2005); Kang et al. (2008); Koppe and Brinkmann (2008); Yeo et al. (2008); Lee and Kim (2010); } \\
\text { Monfort et al. (2011); Golbabaie et al. (2012); Guo and Huang ( 2012); Junliang et al. (2015); Yang } \\
\text { et al. (2014); Kaysi and Nehme (2015) }\end{array}$ \\
\hline $\begin{array}{l}\text { Second- } \\
\text { level criteria }\end{array}$ & Third-level criteria \\
\hline \multirow{5}{*}{ B1 Economic } & C11 Automation cost of CHEs and their electronics for control. \\
\hline & C12 Ground cost, directly linked to the geographic location of the terminal. \\
\hline & C13 Personnel cost for the operation of the CHE. Linked to the automation degree. \\
\hline & $\begin{array}{l}\text { C14 Maintenance cost. Proper maintenance of CHE is a requirement to achieve a green, safe, } \\
\text { secure and resilient ITDG. }\end{array}$ \\
\hline & C15 Expansion cost estimates the price of increasing the terminal capacity in the future. \\
\hline \multirow{5}{*}{ B2 Performance } & $\begin{array}{l}\text { C21 Containers per hour is the amount moved or stored in the terminal in an hour when } \\
\text { operating at full capacity. }\end{array}$ \\
\hline & $\begin{array}{l}\text { C22 Time for serving trucks indicates the average time between a truck (or train) arrival and } \\
\text { departure. }\end{array}$ \\
\hline & C23 Use of door: the percentage of time a door is serving container traffic. \\
\hline & $\begin{array}{l}\text { C24 Equipment inactivity rate: the time containers are without manipulation and therefore } \\
\text { remain inactive. }\end{array}$ \\
\hline & $\begin{array}{l}\text { C25 Time of containers permanence: the average time the containers remain without } \\
\text { manipulation. }\end{array}$ \\
\hline B3 Capacity & $\begin{array}{l}\text { C31 Storage capacity: number of containers that can be stored in the yard, depending on the } \\
\text { stacking possibilities of the CHE used. }\end{array}$ \\
\hline
\end{tabular}




\begin{tabular}{|c|c|}
\hline & $\begin{array}{l}\text { C32 Number of lanes per door: number of possible simultaneous inputs / outputs through the } \\
\text { door. }\end{array}$ \\
\hline & C33 Number of cranes per door to serve the trucks or trains. \\
\hline & $\begin{array}{l}\text { C34 Number of containers moved per hour, considering the container movement time } \\
\text { because the movement is ordered until the } \mathrm{CHE} \text { is ready for a new cycle. }\end{array}$ \\
\hline \multirow{3}{*}{ B4 Expansion } & C41 Expansion possibility once the initial construction capacity is exceeded. \\
\hline & $\begin{array}{l}\text { C42 Expansion complexity measures the difficulty for the system to expand its capabilities in the } \\
\text { future. }\end{array}$ \\
\hline & C43 Expansion time indicates the period of time needed to extend the capabilities of the terminal. \\
\hline \multirow{3}{*}{ B5 Functionality } & C51Automation level, estimated by the number of operators required by the system to work. \\
\hline & $\begin{array}{l}\text { C52 Usability indicates the level of simplicity of the automation. Very complex systems require } \\
\text { training courses and more skilled workers. }\end{array}$ \\
\hline & $\begin{array}{l}\text { C53 Scenario change: adaptability of the machine to work under different scenarios (outdoors, } \\
\text { under cover or inside a warehouse. }\end{array}$ \\
\hline
\end{tabular}

Table 1. Second and third-level criteria for Equipment area, together with literature used for their identification.

The design and management of cost-efficient container terminals using optimisation methods has been increasingly studied in recent last years, especially for the maritime port case. Most of the papers published on the topic focused on the equipment performance in a direct study of costs by means of space optimisation (Lee and Kim 2010), loading-unloading operating time minimization (Guo and Huang, 2012) or fleet size optimisation (Kang et al. 2008), among other methods. In addition to the economic criteria for the equipment area, we have considered other criteria related to the expansion (B4) and functionality possibilities of the used equipment (B5) (Table1). The criteria of the second level were divided into the more specific subcriteria of the third level.

We considered several criteria that may lead to more resilient and safer infrastructures against natural or accidental events such as flood risk (C172), distance to urban core (C163) and evacuation time (C165), among others. The social impact of the facilities should be taken into account through several points of view, and the potential risks associated with vandalism, sabotage and terrorist acts must be foreseen. In this sense, criteria such as equipment reliability (C164), waste system management (C182), control of product transportation (C193), the danger level of the hazardous goods (C161) and automation of processes (C51) were considered. The 
automation of processes is directly linked to the ICT and $\mathrm{BI}$ areas too, where the criteria involving security $(\mathrm{C} 73, \mathrm{C} 123)$ and communications $(\mathrm{C} 81, \mathrm{C} 82, \mathrm{C} 131, \mathrm{C} 132)$ have a direct impact on the global security of the terminal. In ITDGs, it is encouraged to apply management systems that promote a culture of accident prevention through training activities (C213) and procedures (C212) for the performance of the functions of the terminal in a safe working environment for the benefit of the employees, the natural environment and the surrounding population. The social aspects of ITDGs are also linked to the achievement of greener facilities, in which the design should consider reduced energy consumption (C181), the environmental and social vulnerability of the geographic location (B17), waste minimisation, (C192) and management policies (B19) involving preventive measures against pollution (C194), among others.

\begin{tabular}{|c|c|}
\hline \multicolumn{2}{|r|}{ Information and Communications Technology Area } \\
\hline References & $\begin{array}{l}\text { Liu et al. (2002); Saanen et al. (2003); Seyedalizadeh et al. (2009); Lu et al. (2012); Zaghdoud and } \\
\text { Collart-Dutilleul (2013); McKinney et al. (2014) }\end{array}$ \\
\hline $\begin{array}{l}\text { Second- } \\
\text { level }\end{array}$ & Third-level \\
\hline \multirow{5}{*}{$\begin{array}{c}\text { B6 } \\
\text { Infrastructure }\end{array}$} & $\begin{array}{l}\text { C61 Operating system flexibility regarding the necessary operating system to run the servers and } \\
\text { client computers. }\end{array}$ \\
\hline & $\begin{array}{l}\text { C62 Hardware server requirements, such as minimum database space, RAM, and CPU, among } \\
\text { others. }\end{array}$ \\
\hline & $\begin{array}{l}\text { C63 Client software requirements, including PCs, mobile phones, tablets, portable devices, and } \\
\text { smart tags, among others. }\end{array}$ \\
\hline & C64 Database flexibility: applicability of the most suitable databases for the global system. \\
\hline & $\begin{array}{l}\text { C65 Global efficiency estimated by means of the average response time of the application in } \\
\text { normal operating circumstances. }\end{array}$ \\
\hline \multirow{3}{*}{ B7 Quality } & $\begin{array}{l}\text { C71 Operational completeness: existence and functional deepness of important software modules } \\
\text { (web portal, location management, online analytical processing, interactive dashboards scenario } \\
\text { planning and system of automated submissions). }\end{array}$ \\
\hline & $\begin{array}{l}\text { C72 Robustness defines the integrity and availability of alternative process recovery in case of loss } \\
\text { or corruption of data. }\end{array}$ \\
\hline & C73 Security is protection against possible internal or external attacks. \\
\hline \multirow{4}{*}{$\begin{array}{c}\text { B8 } \\
\text { Adaptability }\end{array}$} & C81 Internal communications between the different devices present in the transport terminal. \\
\hline & C82 External communications, such as through web services or real-time integration. \\
\hline & $\begin{array}{l}\text { C83 Process adaptability to the reality of the terminal for the implementation, evolution and } \\
\text { adaptation of the system to future changes to the requirements. }\end{array}$ \\
\hline & C84 Extensions or plugins allowing the extension of the functionality to cover aspects of the \\
\hline
\end{tabular}




\begin{tabular}{|c|c|}
\hline & processes not included in the core. \\
\hline & $\begin{array}{l}\text { C85 Development environments allowing adapting the functionality to specific requirements. } \\
\text { without a large investment. }\end{array}$ \\
\hline \multirow{3}{*}{ B9 Economic } & C91 License costs and annual maintenance. \\
\hline & $\begin{array}{l}\text { C92 Implementation costs of the project or product, adapted to the specific needs of the facility, } \\
\text { including training and consultancy costs. }\end{array}$ \\
\hline & $\begin{array}{l}\text { C93 Maintenance internal cost, considering the dedication required by specialized internal staff to } \\
\text { keep the system running smoothly. }\end{array}$ \\
\hline \multirow{3}{*}{ B10 Usability } & C101 Web access interfaces have advantages in maintenance and usability \\
\hline & $\begin{array}{l}\text { C102 Graphical interface design significantly affects the adoption of the product by the staff in } \\
\text { normal operations and its proper use. }\end{array}$ \\
\hline & $\begin{array}{l}\text { C103 Interfaces other than PCs exist as scanners for labels and mobile devices, among other } \\
\text { forms, and can significantly increase the overall usability of the system. }\end{array}$ \\
\hline
\end{tabular}

Table 2. Second and third-level criteria for Information and Communications Technology area, together with literature used for their identification.

\begin{tabular}{|c|c|}
\hline \multicolumn{2}{|r|}{ Business Intelligence Area } \\
\hline References & Liu et al. (2002); Saanen et al., (2003); Wefeng et al. (2008); Zaghdoud and Collart-Dutilleul (2013) \\
\hline $\begin{array}{l}\text { Second- } \\
\text { level }\end{array}$ & Third-level \\
\hline \multirow{5}{*}{$\begin{array}{l}\text { B11 } \\
\text { Infrastructure }\end{array}$} & $\begin{array}{l}\text { C111 Operating system flexibility defines the necessary operating system to run the servers and } \\
\text { client computers. }\end{array}$ \\
\hline & $\begin{array}{l}\text { C112 Hardware server requirements, such as minimum database space, RAM, and CPU, among } \\
\text { others. }\end{array}$ \\
\hline & $\begin{array}{l}\text { C113 Client software requirements, including PCs, mobile phones, tablets, portable devices, and } \\
\text { smart tags, among others. }\end{array}$ \\
\hline & C114 Database flexibility: applicability of the most suitable databases for the global system. \\
\hline & $\begin{array}{l}\text { C115 Global efficiency estimated by means of the average response time of the application in } \\
\text { normal operating circumstances. }\end{array}$ \\
\hline \multirow{3}{*}{ B12 Quality } & $\begin{array}{l}\text { C121 Operational completeness: existence and functional deepness of important software } \\
\text { modules (warehouse management, operational alarms, business process management, equipment } \\
\text { and machinery management, simulations). }\end{array}$ \\
\hline & $\begin{array}{l}\text { C122 Robustness describes the integrity and availability of alternative process recovery in case of } \\
\text { the loss or corruption of data. }\end{array}$ \\
\hline & C123 Security includes protection against possible internal or external attacks. \\
\hline \multirow{4}{*}{$\begin{array}{c}\text { B13 } \\
\text { Adaptability }\end{array}$} & C131 Internal communications between the different devices present in a transport terminal. \\
\hline & $\begin{array}{l}\text { C132 External communications with other facilities, such as through web services or real-time } \\
\text { integration. }\end{array}$ \\
\hline & $\begin{array}{l}\text { C133 Process adaptability to the reality of the terminal for the implementation, evolution and } \\
\text { adaptation of the system to future changes to requirements. }\end{array}$ \\
\hline & C134 Extensions or plugins allowing the extension of the functionality to cover aspects of the \\
\hline
\end{tabular}




\begin{tabular}{|c|c|}
\hline & processes not included in the core. \\
\hline & $\begin{array}{l}\text { C135 Development environments allowing adapting functionality to specific requirements, without } \\
\text { large investment. }\end{array}$ \\
\hline \multirow{3}{*}{ B14 Economic } & C141 License cost and annual maintenance. \\
\hline & $\begin{array}{l}\text { C142 Implementation cost of the project or product, adapted to the specific needs of the facility, } \\
\text { including training and consultancy costs. }\end{array}$ \\
\hline & $\begin{array}{l}\text { C143 Maintenance internal cost, considering the dedication required by specialized internal staff } \\
\text { to keep the system running smoothly. }\end{array}$ \\
\hline \multirow{3}{*}{ B15 Usability } & C151 Web access interfaces have advantages in maintenance and usability \\
\hline & $\begin{array}{l}\text { C152 Graphical interface design significantly affects the adoption of the product by the staff in daily } \\
\text { activity and its proper use. }\end{array}$ \\
\hline & $\begin{array}{l}\text { C153 Interfaces other than PCs exist as scanners for labels and mobile devices, among other } \\
\text { forms, and can significantly increase the overall usability of the system. }\end{array}$ \\
\hline
\end{tabular}

Table 3. Second and third-level criteria for Business Intelligence area, together with literature used for their identification.

\begin{tabular}{|c|c|}
\hline \multicolumn{2}{|r|}{ Safety and Security Area } \\
\hline References & $\begin{array}{l}\text { Bruzzone and Signorile (1998); Tsai (2006); Badger (2010); Lu and Yang (2010); Mansouri et al. } \\
\text { (2010); Ambrosino and Sciomachen (2012); FHWA (2012); Peilin et al. (2012); Bernechea and } \\
\text { Arnaldos-Viger (2013); Li et al. (2014); Argenti et al. (2015); Assadipour et al. (2015); Zhang et al. } \\
\text { (2015), Axelsen et al. (2016); Ocalir-Akunal (2016); Nogal et al. (2016) }\end{array}$ \\
\hline $\begin{array}{l}\text { Second- } \\
\text { level }\end{array}$ & Third-level \\
\hline \multirow{7}{*}{$\begin{array}{l}\text { B16 Safety } \\
\text { and security }\end{array}$} & $\begin{array}{l}\text { C161 Danger level of the dangerous goods, regarding the potential damage that the product may } \\
\text { cause to people, animals and the environment. }\end{array}$ \\
\hline & $\begin{array}{l}\text { C162 Dangerous goods amount of substances liable to cause damage to people, animals and the } \\
\text { environment. }\end{array}$ \\
\hline & $\begin{array}{l}\text { C163 Distance to the urban core in relation to the fact that toxic compound leakages, thermal } \\
\text { radiation and pressure waves caused in accidents involving dangerous goods can travel large } \\
\text { distances. }\end{array}$ \\
\hline & $\begin{array}{l}\text { C164 Equipment reliability reduces the likelihood of failures, leading to fewer chances that } \\
\text { initiating events of accidents happen. }\end{array}$ \\
\hline & $\begin{array}{l}\text { C165 Evacuation time during an emergency implies the time of exposure of people to the dangers } \\
\text { of an accident and the severity of the consequences. }\end{array}$ \\
\hline & $\begin{array}{l}\text { C166 Density of population in the surrounding areas determines the number of people subject to } \\
\text { the effects associated with an accident }\end{array}$ \\
\hline & $\begin{array}{l}\text { C167 Climatic conditions, such as wind speed and direction that influence the extension of toxic } \\
\text { clouds. Resilience needs to determine how torrential rains or extreme temperatures affect the } \\
\text { design of the facility. }\end{array}$ \\
\hline
\end{tabular}

Table 4. Second and third-level criteria for Safety and Security area, together with literature used for their identification. 
The Information and Communication Technologies area refers to technologies that provide access to information through telecommunications in the supply chain, including internet, wireless networks, cell phones, and smart labels, among other communication mediums (McKinney et al., 2014). This area has a strong role in the global efficiency of the ITDG, together with the Business Intelligence Area. This latter area of criteria focuses on the ability to transform data into information and information into knowledge, to optimize the decision-making process in business (Wefeng et al. 2008). For the two areas of $\mathrm{BI}$ and ICT, analogous criteria of the second and third levels were identified according to the literature and the opinions of the panel of experts.

\begin{tabular}{|c|c|}
\hline \multicolumn{2}{|r|}{ Environment Care Area criteria } \\
\hline References & $\begin{array}{l}\text { Linkov and Ramadan, (2004); Filbrandt (2008); De La Peña-Zarzuelo (2011); Giner-Santonja et al. } \\
\text { (2012); Awad-Núñez et al. (2015); He et al. (2015) Canbulat et al. (2015); Yang et al. (2013) }\end{array}$ \\
\hline $\begin{array}{l}\text { Second- } \\
\text { level }\end{array}$ & Third-level \\
\hline \multirow[t]{5}{*}{ B17 Location } & $\begin{array}{l}\text { C171 Industrial ground availability, allowing the promotion of sustainable urban planning in the } \\
\text { municipality where the facility is located. }\end{array}$ \\
\hline & $\begin{array}{l}\text { C172 Flood risk has a direct impact on the resilience of the ITDG, and the discharge of hazardous } \\
\text { substances due to flooding that can cause pollution disasters that can affect the surface water and } \\
\text { even groundwater in the area. }\end{array}$ \\
\hline & $\begin{array}{l}\text { C173 Available water resources may lead to the implementation of water restriction periods and } \\
\text { resource management plans. }\end{array}$ \\
\hline & $\begin{array}{l}\text { C174 Acoustic impact prediction on the surrounding environment may lead to more socially } \\
\text { inclusive facilities. }\end{array}$ \\
\hline & $\begin{array}{l}\text { C175 Landscape impact prediction on the surrounding environment may lead to more } \\
\text { environmentally friendly facilities. }\end{array}$ \\
\hline \multirow[t]{5}{*}{ B18 Design } & $\begin{array}{l}\text { C181 Energy efficiency (consumption) involving day lighting and thermal insulation to fight } \\
\text { climate change through environmental excellence practices. }\end{array}$ \\
\hline & C182 Waste system management avoiding the hazardous consequences of accidental fluid leaks. \\
\hline & $\begin{array}{l}\text { C183 Protection of groundwater and surface water plan, increasing social inclusion and greener } \\
\text { perspectives of the ITDG. }\end{array}$ \\
\hline & $\begin{array}{l}\text { C184 Hazardous materials storage area conditioning, avoiding the spread of toxic compounds in } \\
\text { case of a leak. }\end{array}$ \\
\hline & $\begin{array}{l}\text { C185 Containers per waste fraction: a lack of foresight in this area can lead to significant } \\
\text { problems of management. }\end{array}$ \\
\hline \multirow[t]{3}{*}{$\begin{array}{c}\text { B19 } \\
\text { Management }\end{array}$} & $\begin{array}{l}\text { C191 Energy efficiency (emissions), favouring the use of equipment that emits less greenhouse } \\
\text { gases. }\end{array}$ \\
\hline & C192 Waste minimisation policies that support the efforts to promote a more sustainable society. \\
\hline & $\begin{array}{l}\text { C193 Scheduling of product transportation and the loading and unloading of materials in the } \\
\text { yard. }\end{array}$ \\
\hline
\end{tabular}




\begin{tabular}{|c|c|}
\hline & $\begin{array}{l}\text { C194 Preventive measures against noise pollution that may impact the natural surroundings and } \\
\text { population; thus, inclusion of facilities must be encouraged. }\end{array}$ \\
\hline & $\begin{array}{l}\text { C195 Sewerage network maintenance, avoiding possible leakage of contaminated water to the } \\
\text { environment in an accident. }\end{array}$ \\
\hline \multirow{4}{*}{$\begin{array}{l}\text { B20 } \\
\text { Construction }\end{array}$} & $\begin{array}{l}\text { C201 Management of construction and demolition waste using an economically and } \\
\text { environmentally viable plan. }\end{array}$ \\
\hline & C202 Minimization of water consumption during the construction of the ITDG. \\
\hline & $\begin{array}{l}\text { C203 Environmental management of equipment, vehicles and facilities during construction by } \\
\text { means of energy efficiency and minimization of emissions and noise. }\end{array}$ \\
\hline & C204 Recovery of topsoil layer plan to be applied after the construction of the ITDG phase \\
\hline \multirow[t]{4}{*}{$\begin{array}{l}\text { B21 } \\
\text { Emergency }\end{array}$} & $\begin{array}{l}\text { C211 Means to address spills in storage in case of managing malfunctions in the ITDG and } \\
\text { disposal of preventive equipment. }\end{array}$ \\
\hline & $\begin{array}{l}\text { C212 Procedures to be applied in case of risk, including handling procedures and management of } \\
\text { abnormal situations and emergencies. }\end{array}$ \\
\hline & C213 Staff training to avoid accidents and manage emergency situations. \\
\hline & $\begin{array}{l}\text { C214 Natural events: rain, storms, frost, earthquakes or extreme temperatures increase risks of } \\
\text { accidents, and the specific needs of the ITDG's resilience must be considered. }\end{array}$ \\
\hline
\end{tabular}

Table 5. Second and third-level criteria for Environment Care, together with literature used for their identification.

\subsection{Criterion prioritisation results}

Experts compared the criteria of the second level and third level by pairs to obtain the global normalised weights $\left(\mathrm{W}_{\mathrm{G}}\right)$ of each one of the 88 criteria and the consistency ratio $(\mathrm{CR})$ of the matrices. The global normalized weights $\left(W_{G}\right)$ for each of the 88 criteria of the third level were calculated as

$$
W_{G}=w_{i} \cdot w_{j} \cdot w_{k}
$$

where $w_{i}$ is the local normalized weight of the criterion of the first level or main area, $w_{j}$ is the normalized weight of the criterion of the second level and $w_{k}$ is the normalized weight of the criterion of third level. The local normalized weights $w_{i}, w_{j}$ and $w_{k}$ were calculated according to the AHP method described by (Saaty, 1980; 2013; 2016).

As a starting point, the experts considered that the five main areas had equal importance, so that all of the criteria of the first level had a local normalized weight $\left(w_{i}\right)$ of 0.2 . To illustrate the process more clearly, Table 6 presents the matrix of comparison obtained for the third level 
criteria of Capacity (B3), included in the Equipment area. The data indicates that criterion C32 (Number of lanes per door) is moderately more important that criterion C33 (Number of cranes per door) or criterion C31 (Storage capacity). C31 has the same importance as C33, and the matrix is consistent, as per the consistency ratio (CR) calculated according to Saaty (2013). CR values higher than 0.1 are not accepted because according to AHP, the matrix should be considered inconsistent. In those cases, the questionnaires affected should be reconsidered. In summary, the $w_{k}$ weights obtained from the matrix show that the most relevant criterion is C34 (Number of containers moved per hour), in the second level cluster of Capacity, belonging to the Equipment area.

\begin{tabular}{|c|c|c|c|c|c|}
\hline $\begin{array}{c}\text { Capacity criteria in } \\
\text { Equipment area } \\
\text { (B3) }\end{array}$ & C31 & C32 & C33 & C34 & wk \\
CR: 0.0454 & 1 & $1 / 3$ & 1 & $1 / 5$ & 0.087095 \\
\hline C31 & & 1 & 3 & $1 / 5$ & 0.199668 \\
\hline C32 & & & 1 & $1 / 7$ & 0.078299 \\
\hline C33 & & & & 1 & 0.634938 \\
\hline C34
\end{tabular}

Table 6. Comparison matrix obtained for the third-level subcriteria belonging to the Capacity criterion cluster (B3) in the general area of Equipment. Values for the consistency ratio of the matrix $(C R)$ and the local normalized weight for the third level criteria $\left(w_{k}\right)$ are shown.

When analysing the results achieved for the applied conditions, $80 \%$ of the sum of $W_{G}$ corresponds to 33 criteria (Fig. 3). The rank of the criteria of the third level according to their $W_{G}$ values provides a prioritisation in order of importance. The results show that the most important criteria to take into account in the design of ITDGs are:

1: The first criterion to be considered in the design of ITDGs is the distance to the urban core (C163), pertaining to the Safety and Security Area. This is the distance in kilometres from the terminal to the nearest population core. The social impact, the influence of the ITDG on the urban area, is directly linked to this criterion. This criterion's importance is mainly related to the 
toxicity of the goods and the risks of thermal radiation and pressure waves that may be produced during accidents involving dangerous substances are involved. Those risks could reach extensive zones from the initiator focus of the event. An underestimation of this criterion could result in a higher probability of irreparable damage or injury to extensive fractions of population. In this research, the prevention of disasters is a key criterion that would be irrelevant in the design of a conventional terminal, making a clear difference in the requirements for facilities that handle containers with dangerous goods.

2: $\quad$ The parameter in the second position is ground cost $(\mathrm{C} 12)$, belonging to the main area of Equipment. This parameter was considered as a quantification of the land cost measured in euros per square meter. Of course, the feasibility of a project necessarily involves profitability. Otherwise, we would be designing systems with little real applicability, so that the economic criteria have great relevance. Depending on the selection of the geographic location, the urbanization of rural zones might be necessary, which could modify the final cost. This criterion is closely linked to the type of machines installed in the terminal because as a function of its typology, the layout of the terminal may require a specific surface area which may also depend on its stacking possibilities (Monfort et al., 2011).

3: In the third place is the availability of industrial floor area (C171) without the need to reassess rural lands, in the area of Environment. It is considered the most beneficial criterion to the promoter of the project and to safeguard sustainable urban planning in the municipality. It is imperative to choose a suitable geographic location for the terminal that does not damage rural or protected zones. The expert panel considers it reasonable to take in the environmental requirements into account as a main criterion of the geographic location of the ITDG to achieve more resilient infrastructures. The risks related to extreme weather events should also not be neglected, and the sensible placement of the ITDG is directly linked to the potential risks of the facility.

4: Dangerousness level of dangerous goods (C161) of the area of Safety and Security has a strong importance because the installations that pose greater risks to people, animals and the environment are those that have substances of greater dangerousness. This criterion is not only 
relevant to minimising the risk associated with possible unintentional accidents, but we should also have in mind other relevant concerns related to security. When highly dangerous goods are handled, the possibility of vandalism attacks or terrorist acts should be considered to avoid the consequences of potential disasters.

5: In this position, criteria pertaining to the areas of ICT and BI appear. The first criterion in importance for the experts is the implementation cost (C142) among the economic criteria in the $\mathrm{BI}$ area. The expert board considered it reasonable that the costs of the implementation of a software of the field $\mathrm{BI}$ would be more important than the costs related to the implementation of the operative software of the ICT because the BI software usually comprises more specific and concrete modules that require more implementation time in the terminal that the ICT software.

6 and 7: $\quad$ Following those most relevant criteria, C91, corresponding to license costs in the ICT area ranks sixth. In the seventh position is C92, the criterion related to the implementation or adaptation cost of the software to the specific needs of the terminal corresponding to the ICT main area. This criterion includes the cost of internal dedicated hours and the hours of external consulting and development. The C91 and C92 criteria were given the same global weight.

8 and 9: In eighth and ninth places are the operational completeness of the areas of ICT (C71) and $\mathrm{BI}$ (C121). The functionality of the software with respect to the existence and functional depth of some specific modules were considered relevant. Thus, for the ICT area, it would be recommended that applications exist for the management of locations, management of warehouses, control of teams and machinery, and capacity to make simulations and monitor processes. In the $\mathrm{BI}$ area, the existence of software able to upload and process data from many origins, interactive dashboards, a planning stage system, and automatic message sending would be valuable, among other modules.

10. The tenth criterion in order of greatest $W_{G}$ was $C 41$, regarding the cost of the licenses of the software in the $\mathrm{Bl}$ area and their periodic maintenance.

Appendix A shows the local normalized weights for the second-level criteria $w_{j}$ and thirdlevel criteria $w_{k}$. 


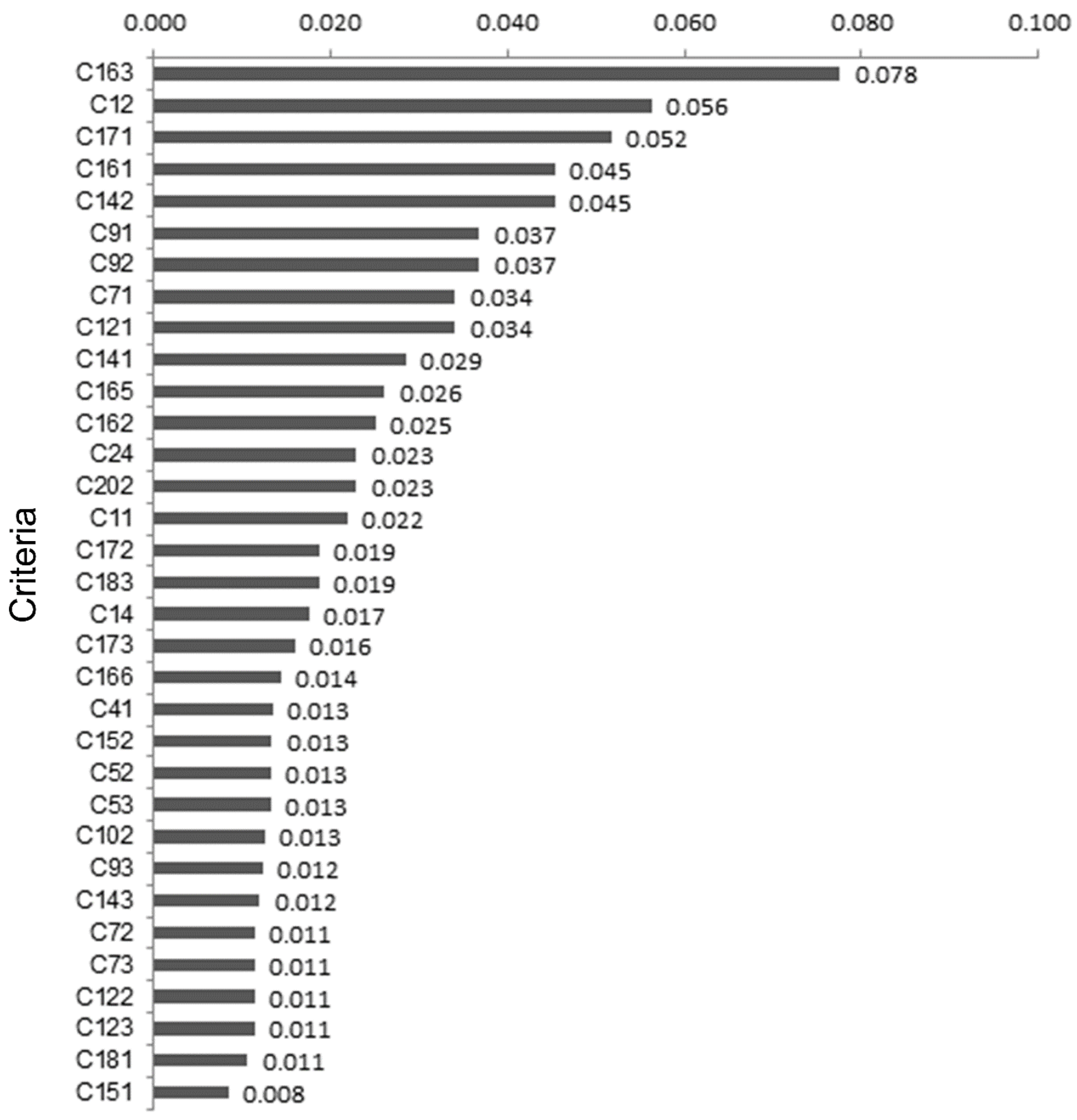

Fig. 3 Criteria of third level with greatest $W_{G}$, representing $80 \%$ of the sum of the $W_{G}$ when $W_{i}$ is the same for all first-level criteria. 


\subsection{Sensitivity analysis}

AHP allows performing a sensitivity analysis supposing minor changes in the judgments of the final decisions (Al-Harbi, 2001). The analysis of the sensitivity evaluates the way in which the $W_{G}$ for each criterion may change when varying $W_{i}$ in the first hierarchy level. Specifically, we studied the variation of the relative importance of the criteria of the third level in the $W_{G}$ rank when modifying the value of $w_{i}$. We varied in five independent experiments the value of $w_{i}$ for each criterion of the first level from 0.2 to 0.3 , while the other four $w_{i}$ criteria retained a value of 0.175 .

Through the analysis of the sensitivity, we obtained that for the ten criteria with initial greater weights, few changes in the $W_{G}$ rank happened when changing the value of $w_{i}$ for the Equipment or Environment care areas (Table 7). Therefore, it seems to be a robust and reliable result because the criteria representing $80 \%$ of the sum of the $W_{G}$ are practically the same in all of the simulated scenarios. Appendix B shows the rank of priorities of the most relevant criteria of the third-level analysis when increasing the values of the $w_{i}$ of the main areas of Equipment, ICTs, BI, Safety and Security and Environment care.

\begin{tabular}{|c|c|c|c|c|c|c|}
\hline Criterion & $\begin{array}{c}\mathbf{W}_{\mathrm{i}} \\
(\mathrm{all})= \\
0.2\end{array}$ & $\begin{array}{c}\mathbf{W}_{\mathrm{i}} \\
\text { (Equipment) } \\
=0.3\end{array}$ & $\begin{array}{c}\mathrm{W}_{\mathrm{i}} \text { (ICTs) } \\
=0.3\end{array}$ & $\begin{aligned} & W_{i} \\
&(B I) \\
&=0.3\end{aligned}$ & $\begin{array}{c}\mathbf{W}_{\mathbf{i}} \\
\text { (Safety and } \\
\text { Security) }=0.3\end{array}$ & $\begin{array}{c}w_{i}(\text { Environment care })= \\
0.3\end{array}$ \\
\hline C163 & 0.078 & 0.068 & 0.068 & 0.068 & 0.116 & 0.068 \\
\hline C12 & 0.056 & 0.084 & 0.049 & 0.049 & 0.049 & 0.049 \\
\hline C171 & 0.052 & 0.045 & 0.045 & 0.045 & 0.03 & 0.040 \\
\hline C161 & 0.045 & 0.040 & 0.04 & 0.04 & 0.068 & 0.040 \\
\hline C142 & 0.045 & 0.040 & 0.04 & 0.068 & 0.040 & 0.040 \\
\hline C91 & 0.037 & 0.032 & 0.055 & 0.032 & 0.032 & 0.032 \\
\hline
\end{tabular}




\begin{tabular}{|c|c|c|c|c|c|c|}
\hline C92 & 0.037 & 0.032 & 0.055 & 0.032 & 0.032 & 0.032 \\
\hline C71 & 0.034 & 0.030 & 0.051 & 0.030 & 0.030 & 0.030 \\
\hline C121 & 0.034 & 0.030 & 0.030 & 0.051 & 0.030 & 0.030 \\
\hline C141 & 0.029 & 0.023 & 0.025 & 0.043 & 0.025 & 0.025 \\
\hline C202 & 0.023 & 0.020 & 0.020 & 0.020 & 0.020 & 0.034 \\
\hline C165 & 0.026 & 0.023 & 0.023 & 0.023 & 0.039 & 0.023 \\
\hline
\end{tabular}

Table 7. Most influential criteria under all circumstances considered in the study of sensitivity.

\section{Conclusions}

Addressing hazardous substances to safe, green and efficient inland terminals for containers with dangerous goods (ITDGs) helps to decrease the risks of more socially inclusive seaports. It is also a part of the solution to seaport terminal congestion, reducing $\mathrm{CO}_{2}$ emissions in transport operations linked with port activities (Roso, 2007).

This paper provides researchers, designers, managers and other public and private interested entities with factors to be considered in the design of these ITDGs from a total safety management point of view from the earliest stages of the project. The prioritization of these factors to achieve safer, greener, and more efficient multimodal infrastructures have a direct impact on achieving more socially inclusive facilities in a synchromodal, sustainable and seamless supply chain network development.

A holistic approach has been taken, considering highly relevant aspects besides safety and security, such as efficiency, environment care, BI and ICT. The AHP method allowed us to make a global comparison, which is especially relevant for intangible criteria prioritisation (Saaty, 2016). The establishment of a systematically structured methodology has contributed to the identification and weighting of criteria with a direct influence on the design of ITDGs.

We have concluded that, for the design of ITDGs: (i) the safety criterion of distance to the urban core, (ii) the harmful properties of the goods, (iii) the economic criterion related to the cost 
of the ground, and the environmental concerns through (iv) the utilization of industrial flooring instead of a rural one, are the critical factors. Nevertheless, besides these extremely important criteria, the ICT and $\mathrm{BI}$ criteria strongly emerge, occupying from the fifth to the tenth positions in the ranking. Among those criteria, the costs of the implantation of these ICT and BI systems and their licensing costs seem to be the most relevant for ITDG managers. The fact that the safety, security and environmental criteria are as relevant as the cost criteria is remarkable, and it is aligned with the fact that dangerous goods are handled in the inland terminal.

It must be pointed out that AHP method defines a panel of experts so that the conclusions achieved are supposed to be universal, but does not provide a system for the selection the experts. In this case we have chosen the expert panel according to Skateholders theory (Reynolds et al., 2006). Skateholder theory cannot ensure the universality of the results; it depends on the circumstances of each decision-maker. AHP methods raise subjectivities of the expert panel, but precisely this method has been selected as the only (along with ANP), to assign numerical values to intangible criteria (which cannot be measured) related to safety concerns. This limitation has been circumvented in this work through a sensitivity study assessing the robustness of the method to variations in the preferences panel of experts through a sensitivity analysis. This holistic analysis of the criteria involved in the basic design of the ITDGs has been shown to be robust, and it opens an interesting line of research in the field of safety applied to transport and logistics into a total performance management (environment and productivity). Our research group is involved on further developments of the technique, identifying alternatives that best fit with those criteria. Future perspectives may include the consideration and comparison of the results achieved among different groups of local experts coming from different geographic locations and with different concerns to be addressed.

\section{Acknowledgements}

The author thanks the expert board for their contributions (sorted alphabetically): AIMME (expert 4), AITEC (expert 1), IMEDES (expert 2), JOFESA (expert 3) and LITEBI (expert 5). Public funding entity: GENERALITAT VALENCIANA. 


$\begin{array}{ll}\text { Glossary } & \\ \text { AHP } & \text { Analytic hierarchical process } \\ \text { BI } & \text { Business intelligence } \\ \text { CHE } & \text { Container Handling Equipment } \\ \text { CBA } & \text { Cost-benefit analysis } \\ \text { CR } & \text { Consistency ratio } \\ \text { ICT } & \text { Information and communications technology } \\ \text { IMDG } & \text { International Maritime Dangerous Goods } \\ \text { ITDG } & \text { Inland terminals of containers with dangerous goods } \\ \text { MCDA } & \text { Multicriteria Decision Analysis } \\ \text { MCDM } & \text { Multicriteria Decision Making } \\ \text { W } & \text { Global normalized weight of criterion versus the goal } \\ \text { W }_{\mathrm{i}} & \text { Local normalized weight of a first-level criterion } \\ \text { W }_{\mathrm{j}} & \text { Local normalized weight of a second-level criterion } \\ \text { W }_{\mathrm{k}} & \text { Local normalized weight of a third-level criterion }\end{array}$

\section{References}

Agwu, M. O., 2012. Total Safety Management: A Strategy for Improving Organisational Performance in Selected Construction Companies in Nigeria. International Journal of Business \& Social Science 3 (20), 210-217.

Al-Harbi, K. M. A. S., 2001. Application of the AHP in project management. International Journal of Project Management, 19(1), 19-27. doi:10.1016/S0263-7863(99)00038-1

Ambrosino, D., Sciomachen, A., 2012. How to reduce the impact of container flows generated by a maritime terminal on urban transport. WIT Transactions on Ecology and the Environment, 167, 79-88. doi: 10.2495/ST110081

Antão, P., Calderón, M., Puig, M., Michail, A., Wooldridge, C., Darbra, R. M., 2016. Identification of Occupational Health, Safety, Security ( OHSS ) and Environmental Performance Indicators in port areas. Safety Science, 85, 266-275. http://doi.org/10.1016/j.ssci.2015.12.031

Aragonés-Beltrán, P., Chaparro-González, F., Pastor-Ferrando, J.-P., Pla-Rubio, A., 2014. An AHP (Analytic Hierarchy Process)/ANP (Analytic Network Process)-based multi-criteria decision approach for the selection of solar-thermal power plant investment projects. Energy, 66, 222-238. doi: 10.1016/j.energy.2013.12.016 
Argenti, F., Landucci, G., Spadoni, G., Cozzani, V., 2015. The assessment of the attractiveness of process facilities to terrorist attacks. Safety Science, 77, 169-181. http://doi.org/10.1016/j.ssci.2015.02.013

Armería, D.A.P., De La Fuente, J.G.R., 2015. Improving safety and reducing risks. An integral solution supporting operational discipline in PEMEX. Society of Petroleum Engineers - SPE Digital Energy Conference and Exhibition 2015, 243-250,3-5 March, The Woodlands, Texas, USA, . doi: 10.2118/173410-MS

Assadipour, G., Ke, G. Y., Verma, M., 2015. Planning and managing intermodal transportation of hazardous materials with capacity selection and congestion. Transportation Research Part E, 76, 45-57. doi:10.1016/j.tre.2015.02.003

Awad-Núñez S., González-Cancelas N., Soler-Flores F., Camarero-Orive A., 2015. How should the sustainability of the location of dry ports be measured? A proposed methodology using Bayesian networks and multi-criteria decision analysis. Transport, 30 (3), 312-319.

doi:10.3846/16484142.2015.1081618

Axelsen C., Grauert M., Liljegren E., Bowe M., Sladek B., 2016. Implementing climate change adaptation for European road administrations. Proceedings of 6th Transport Research Arena, April 18-21, 2016, Warsaw, Poland

Badger, S.G., 2010. Large-loss Fires in the United States-2009, Fire Analysis and Research Division. National Fire Protection Association, USA, November

Bask, A., Roso, V., Andersson, D., Hämäläinen, E., 2014. Development of seaport-dry port dyads: Two cases from Northern Europe. Journal of Transport Geography, 39, 85-95. doi: 10.1016/j.jtrangeo.2014.06.014

Beresford, A. K.C., Pettit S.J., Wu Q., Williams S., 2012. A study of dry port development in China. Maritime Economics \& Logistics, 14 (1), 73-98.

doi:10.1057/mel.2011.17

Bernechea E.J., Arnaldos-Viger J., 2013. Design optimization of hazardous substance storage facilities to minimize project risk. Safety Science, 51 (1), 49-62.

Bruzzone A., Signorile R., 1998. Simulation and genetic algorithms for ship planning and shipyard layout. Simulation, 71 (2), 74-83.

doi: $10.1177 / 003754979807100202$ •

Canbulat, O., Aymelek, M., Kurt, I., Koldemir, B., Turan, O., 2015. The green sustainable performance comparison of the three biggest container terminals in Turkey. in Proceedings of International Association of Maritime Economists (IAME) 2015 Conference.

Clott, C., Hartman, B. C., 2016. Supply chain integration, landside operations and port accessibility in metropolitan Chicago. Journal of Transport Geography, 51:130-139. doi: 10.1016/j.jtrangeo.2015.12.005

Cullinane, K., Wang, T., Song, D., Ji, P., 2006. The technical efficiency of container ports: Comparing data envelopment analysis and stochastic frontier analysis. Transportation Research Part A: Policy and Practice, 40(4), 354-374. doi: 10.1016/j.tra.2005.07.003

De La Peña-Zarzuelo, I., 2011. Port of Ferrol enlargement works en Proceedings of the institution of civil engineers-maritime engineering 164, (2), 49-58. Doi: 10.1680/maen.2011.164.2.49 
Delgado-Galván X., Izquierdo J., Benítez J., Pérez-García R., 2014. Joint stakeholder decisionmaking on the management of the Silao-Romita aquifer using AHP. Environmental Modelling and Software 51, 310-322. doi: 10.1016/j.envsoft.2013.10.008

EEA (2014) Adaptation of transport to climate change in Europe. European Environment Agency. EEA Report No 8/2014

doi: $10.2800 / 242209$

Filbrandt, U., 2008. Sustainable port development container terminals in Bremerhaven. Proceedings of the Chinese-German joint symposium on hydraulic and ocean engineering, 299303 Edited by: Zanke, U; Roland, A; Saenger, N; Wiesemann, JU; Dahlem, G

FHWA, 2012. Climate change and extreme weather vulnerability assessment framework. Federal Highway Administration of U.S. Department of Transportation, FHWA Publication No: FHWAHEP-13-005

hhttps://www.fhwa.dot.gov/environment/climate_change/adaptation/publications/vulnerability_ass essment_framework/

Flämig, H., Hesse, M., 2011. Placing dryports. Port regionalization as a planning challenge - The case of Hamburg, Germany, and the Süderelbe. Research in Transportation Economics, 33(1), 42-50. doi: 10.1016/j.retrec.2011.08.005

Gambardella, L. M., Mastrolilli, M., Rizzoli, A. E., Zaffalon, M., 2001. An optimization methodology for intermodal terminal management. Journal of Intelligent Manufacturing, 12(5-6), 521-534. doi:10.1023/A:1012208605758

Giner-Santonja, G., Aragonés-Beltrán, P., Niclós-Ferragut, J, 2012. The application of the analytic network process to the assessment of best available techniques. Journal of Cleaner Production 25, 86-95. doi: 10.1016/j.jclepro.2011.12.012

Golbabaie, F., Seyedalizadeh Ganji, S. R., Arabshahi, N., 2012. Multi-criteria evaluation of stacking yard configuration. Journal of King Saud University - Science, 24(1), 39-46. doi: 10.1016/j.jksus.2010.08.010

Guo, X., and Huang, S. Y., 2012. Dynamic Space and Time Partitioning for Yard Crane Workload Management in Container Terminals. Transportation Science, 46(1), 134-148. doi:10.1287/trsc. 1110.0383

Hanaoka, S., Regmi, M. B., 2011. Promoting intermodal freight transport through the development of dry ports in Asia: An environmental perspective. IATSS Research, 35(1), 16-23. doi:10.1016/j.iatssr.2011.06.001

Harik R., El-Hachem W., Medini K., Bernard A., 2005 Towards a holistic sustainability index for measuring sustainability of manufacturing companies. International Journal of Production Research 53 (13), 4117-4139. doi: 10.1080/00207543.2014.993773

He, J., Huang, Y., Yan, W., Wang, S., 2015. Integrated internal truck, yard crane and quay crane scheduling in a container terminal considering energy consumption. Expert Systems with Applications, 42(5), 2464-2487. doi: 10.1016/j.eswa.2014.11.016

Holguín-Veras, J., 1995. Comparative Assessment of AHP and MAV in Highway Planning: Case Study. Journal of Transportation Engineering, 121(2), 191-200. doi: 10.1061/(ASCE)0733947X(1995)121:2(191) 
Huang, W. C., Teng, J. Y., Huang, M. J., Kou, M. S., 2003. Port competitiveness evaluation by fuzzy multicriteria grade classification model. Journal of Marine Science and Technology, 11(1), 53-60.

Huang, P., Zhang, J., 2015. Facts related to August 12, 2015 explosion accident in Tianjin, China. Process Safety Progress, Article in Press. doi: 10.1002/prs.11789

He, J., Huang, Y., Yan, W., Wang, S., 2015. Integrated internal truck, yard crane and quay crane scheduling in a container terminal considering energy consumption. Expert Systems with Applications, 42(5), 2464-2487.doi: 10.1016/j.eswa.2014.11.016

Kaysi I.A., Nehme, N., 2015. Optimal investment strategy in a container terminal: A game theoretic approach. Maritime Economics and Logistics, advance online publication. doi: 10.1057/mel.2015.7

Kang, S., Medina, J. C., Ouyang, Y., 2008. Optimal operations of transportation fleet for unloading activities at container ports. Transportation Research Part B: Methodological, 42(10), 970-984. doi:10.1016/j.trb.2008.02.003

Kim, K. H., Kim, H. B. (2002). The optimal sizing of the storage space and handling facilities for import containers. Transportation Research Part B: Methodological, 36(9), 821-835. doi: 10.1016/S0191-2615(01)00033-9

Koppe, B., Brinkmann, B. (2008) State of the art of handling and storage system on container terminals, Chinese-German Joint Symposium on Hydraulic and Coastal Engineering, August 2430, 2008 (Damstadt, Germany) 57-61.

Lee, B. K., and Kim, K. H., 2012. Optimizing the yard layout in container terminals. OR Spectrum, 35(2), 363-398. doi: 10.1007/s00291-012-0298-z

Lee J., 2015. A holistic decision-making framework for selecting domestic piping materials Journal of Water Supply: Research and Technology - AQUA, 64 (3), 326-332. doi: 10.2166/aqua.2015.088

Linkov I., Ramadan, A.B., 2004. Comparative Risk Assessment and Environmental Decision Making. Springer Netherlands. doi 10.1007/1-4020-2243-3

Linstone, H.A., Turoff M., 1975. The Delphi method: techniques and applications. AddisonWesley Pub. Co., Advanced Book Program.

Li, Y., Ping, H., Ma, Z.-H., Pan, L.-G., 2014. Statistical analysis of sudden chemical leakage accidents reported in China between 2006 and 2011. Environmental Science and Pollution Research, 21 (8), 5547-5553. doi: 10.1007/s11356-013-2279-4

Liu, C. I., Jula, H., Ioannou, P. A., 2002. Design, simulation, and evaluation of automated container terminals. IEEE Transactions on Intelligent Transportation Systems, 3(1), 12-26. doi: $10.1109 / 6979.994792$

Lu, C., Yang, C., 2010. Safety leadership and safety behavior in container terminal operations. Safety Science, 48(2), 123-134. http://doi.org/10.1016/j.ssci.2009.05.003

Lu, H.J., Zhen, H.Q., Chang, D.F., 2012. Visualization Method of Bucket Terminal Yard Working Data Applied Mechanics and Materials 178, 2770-2774 
Mansouri M., Nilchiani R., Mostashari A., 2010. A policy making framework for resilient port infrastructure systems. Marine Policy, 34(6), 1125-1134. doi: 10.1016/j.marpol.2010.03.012

Martínez-Rojas, M., Marín, N., Vila, M.A., 2016, The role of information technologies to address data handling in construction project management. Journal of Computing in Civil Engineering, 30 (4), art. no. 04015064. doi: 10.1061/(ASCE)CP.1943-5487.0000538

Molero, GD., 2016. Análisis de criterios de diseño básico de una terminal de contenedores de sustancias químicas peligrosas aplicando el proceso analítico jerárquico (AHP) [Analysis of criteria for the basic design of a container terminal of hazardous goods applying Analytic Hierarchy Process (AHP)]. Universitat Politècnica de València. doi:10.4995/Thesis/10251/61773

Monfort, A., Aguilar J., Vieira, P., Monterde, N., Obrer, R., Calduch, D., Martín, A.M., Sapiña, R., (2011) Manual de capacidad portuaria: aplicación a terminales de contenedores, (Fundación VALENCIAPORT, Valencia)

Monios, J., Bergqvist, R., 2015. Intermodal terminal concessions: Lessons from the port sector. Research in Transportation Business and Management, 14, 90-96. doi: 10.1016/j.rtbm.2014.09.002

Monios, J., Wilmsmeier, G., 2012. Giving a direction to port regionalisation. Transportation Research Part A: Policy and Practice, 46(10), 1551-1561.doi: 10.1016/j.tra.2012.07.008

Nogal M., O'Connor A., Caulfield B., Brazil W., 2016. A multidisciplinary approach for risk analysis of infrastructure networks in response to extreme weather. Proceedings of 6th Transport Research Arena, April 18-21, 2016, Warsaw, Poland

Ocalir-Akunal, E. V., 2016. Using Decision Support Systems for Transportation Planning Efficiency (pp. 1-475). Hershey, PA: IGI Global. doi:10.4018/978-1-4666-8648-9.

Palacio A , Adenso Díaz, B., Lozano S., 2015. A decision-making model to design a sustainable container depot logistic network: the case of the Port of Valencia. Transport, Article in Press. doi: $10.3846 / 16484142.2015 .1107621$

Peilin, Z., Jian, M., Long, Y., 2012. Research on Layout Evaluation Indexes System of Dangerous Goods Logistics Port Based on AHP, 2, 943-949.

Portugal, L.S., Morgado, A. V., Júnior, O. L. (2011). Location of cargo terminals in metropolitan areas of developing countries: the Brazilian case. Journal of Transport Geography, 19(4), 900910. doi:10.1016/j.jtrangeo.2010.11.005

Reynolds, S. J., Schultz, F. C., Hekman, D. R., 2006. Stakeholder Theory and Managerial Decision-Making: Constraints and Implications of Balancing Stakeholder Interests, Journal of Business Ethics, 64:285-301.

Romero, N., Nozick, L. K., Xu, N., 2016. Hazmat facility location and routing analysis with explicit consideration of equity using the Gini coefficient. Transportation Research Part E, 89, 165-181. doi: 10.1016/j.tre.2016.02.008

Roso, V., 2007. Evaluation of the dry port concept from an environmental perspective: A note. Transportation Research Part D Transport and Environment 12(7), 523-527. doi: 10.1016/j.trd.2007.07.001 
Saanen, Y., VanMeel, J., Verbraeck, A., 2003. The design and assessment of next generation automated container terminals. Simulation In Industry Published: 15th European Simulation Symposium, Delft, The Netherlands, 577-584

Saaty, T.L., 1980. The Analytic Hierarchy Process, Planning, Piority Setting, Resource Allocation. McGraw-Hill, New York.

Saaty, T. L., 2013. The analytic network process. Decision Making with the Analytic Network Process, 195, 1-40. doi: 10.1007/978-1-4614-7279-7_1

Saaty, T.L., 2016. The analytic hierarchy and analytic network processes for the measurement of intangible criteria and for decision-making. International Series in Operations Research and Management Science, 233, 363-419. doi: 10.1007/978-1-4939-3094-4_10

Seyedalizadeh S.R., Javanshir H, Vaseghi F., 2009. Nonlinear mathematical programming for optimal management of container terminals. Int. J. Modern Phys. B, 23 (27)), p. 5333-5342 doi: 10.1142/S021797920905345X

Tappura, S., Sievänen, M., Heikkilä, J., Jussila, A., Nenonen, N., 2015. A management accounting perspective on safety. Safety Science 71 B, 151-159. doi: dx.doi.org/10.1016/j.ssci.2014.01.011.

Teng, J., Huang, W., Huang, M., 2004. Multicriteria evaluation for port competitiveness of eight east. Journal of Marine Science and Technology, 12(4), 256-264.

Tramarico, C. L., Salomon, V. A. P., Marins, F. A. S., 2015. Analytic Hierarchy Process and Supply Chain Management: A Bibliometric Study. Procedia Computer Science, 55(Itqm), 441450. doi: 10.1016/j.procs.2015.07.005

Tsai, M. C., 2006. Constructing a logistics tracking system for preventing smuggling risk of transit containers. Transportation Research Part A: Policy and Practice, 40(6), 526-536. doi: 10.1016/j.tra.2005.11.001

UNCTAD, 2014. United Nations Conference on Trade and Development, Review of Maritime Transport 2014, United Nations Publication, available at http://unctad.org/en/PublicationsLibrary/rmt2014_en.pdf

Vaidya, O. S., Kumar, S., 2006. Analytic hierarchy process: an overview of applications. European Journal of Operational Research, 169(1), 1-29. doi: 10.1016/j.ejor.2004.04.028

Vis, I.; Koster, R.; Savelsbergh, M. , 2005. Minimum Vehicle Fleet Size Under Time-Window Constraints at a Container Terminal. Transportation Science, 39(2), 249-260.

doi:10.1287/trsc. 1030.0063

Wallenius, J., Dyer, J. S., Fishburn, P. C., Steuer, R. E., Zionts, S., Deb, K., 2008. Multiple Criteria Decision Making, Multiattribute Utility Theory: Recent Accomplishments and What Lies Ahead. Management Science, 54(7), 1336-1349. doi:10.1287/mnsc.1070.0838

Wiegmans, B. W., Louw, E., 2011. Changing port - city relations at Amsterdam: A new phase at the interface? Journal of Transport Geography, 19(4), 575-583. doi: 10.1016/j.jtrangeo.2010.06.007

Yang, C.-C., Tai, H.-H. Chiu, W.-H., 2014. Factors influencing container carriers' use of coastal shipping. Maritime Policy \& Management, 41(2), 192-208. doi: 10.1080/03088839.2013.818729 
Yang, Y. C., Lin, C. L., 2013. Performance analysis of cargo-handling equipment from a green container terminal perspective. Transportation Research Part D: Transport and Environment, 23, 9-11. doi: 10.1016/j.trd.2013.03.009

Yeo, G. T., Roe, M., Dinwoodie, J., 2008. Evaluating the competitiveness of container ports in Korea and China. Transportation Research Part A: Policy and Practice, 42(6), 910-921. doi: 10.1016/j.tra.2008.01.014

Zaghdoud, R., Collart-Dutilleul, S., 2013. A Multi-objective Approach for Assignment Containers to AIVs in a Container Terminal, IEEE International Conference on Systems, Man and Cybernetics, 2460-2466. doi: 10.1109/SMC.2013.420

Zhang, X., Miller-Hooks, E. Denny, K. 2015. Assessing the role of network topology in transportation network resilience. Journal of Transport Geography, 46, 35-45. doi: 10.1016/j.jtrangeo.2015.05.006

Zhang, M., Pel, A. J., 2016. Synchromodal hinterland freight transport: Model study for the port of Rotterdam. Journal of Transport Geography, 52, 1-10. doi: 10.1016/j.jtrangeo.2016.02.007

Zhi, X., Lai, C., Zhang, C., (2012) Model of total safety management (TSM) and its application. 2012 International Symposium on Safety Science and Technology. Procedia Engineering 45, 204 - 207, doi: 10.1016/j.proeng.2012.08.144

\section{Web references}

CEFIC, 2015. European Chemical Industry Council http://www.cefic.org/Facts-and-Figures/ (August, 2015)

EC, 2016. Horizon 2020 -Work Programme Transport 2016-2017 (Smart, green and integrated transports) European Commission Decision C(2016)1349 (March, 2016)

http://ec.europa.eu/research/participants/data/ref/h2020/wp/2016_2017/main/h2020-wp1617transport_en.pdf

MT, 2015. Mobility and transport,

http://ec.europa.eu/transport/road_safety/topics/vehicles/cargo_securing_loads/index_en.htm (October, 2015)

SCOPUS, 2016. https://www.scopus.com/ (May, 2016)

TraConference, 2014. http://tra2014.traconference.eu/ (May, 2014)

TraConference, 2016. http://www.traconference.eu/ (May, 2016)

COP21 Paris Climat, 2015. http://www.ifsttar.fr/en/europe-international/conferences/cop21-parisclimat-2015/ (May, 2016)

UNECE, 2015. United Nations Economic Commission for Europe, European Agreement concerning the International Carriage of Dangerous Goods by Road, http://www.unece.org/trans/danger/publi/adr/adr2015/15contentse.html (March 2016) 


\section{Appendices}

Appendix A
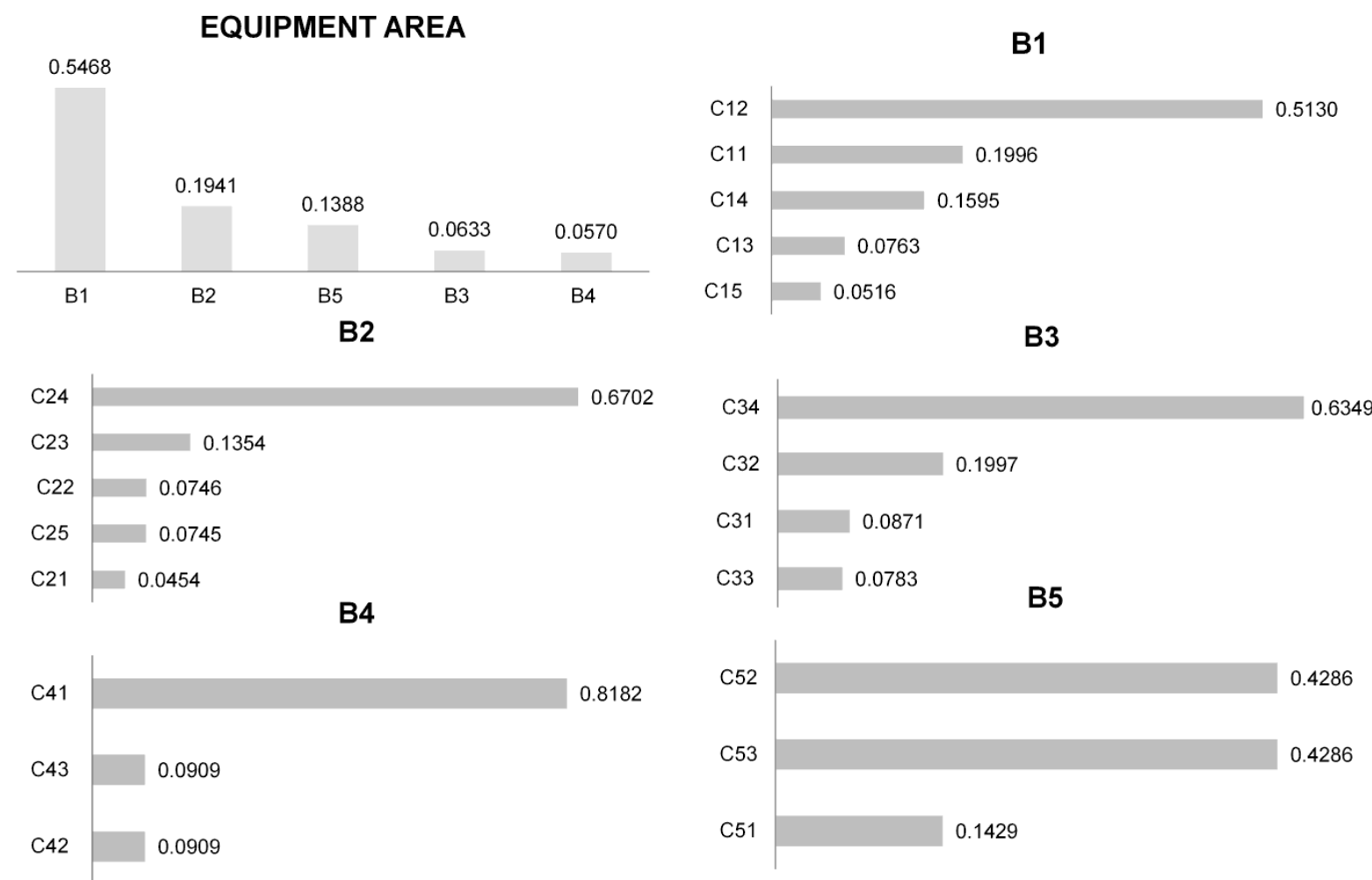

Fig. A.1. $w_{j}$ values achieved for criteria of second level in the Equipment area and $w_{k}$ values achieved for the criteria of the third level in B1, B2, B3, B4 and B5 clusters of subcriteria. 
ICT AREA

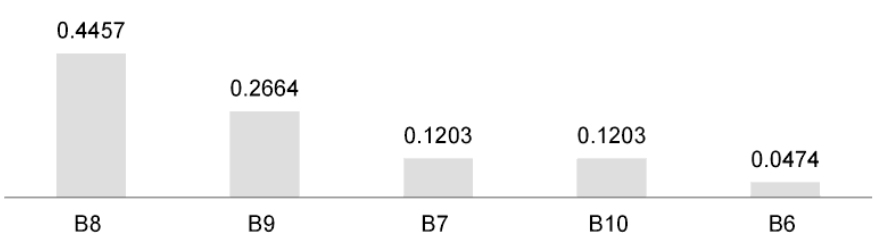

B7

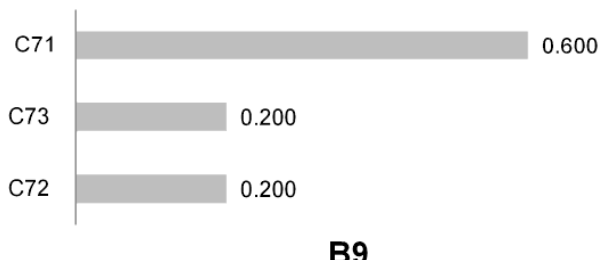

B9

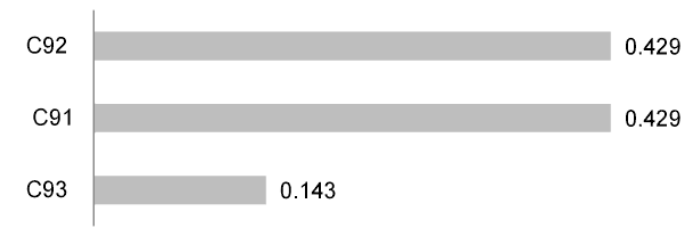

B6

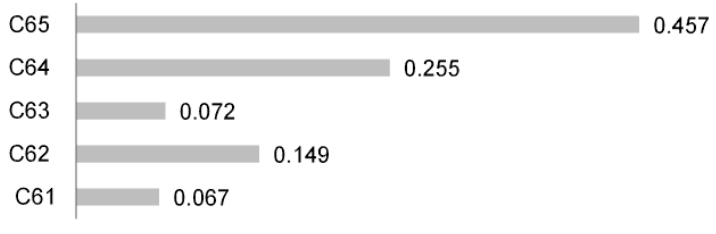

B8
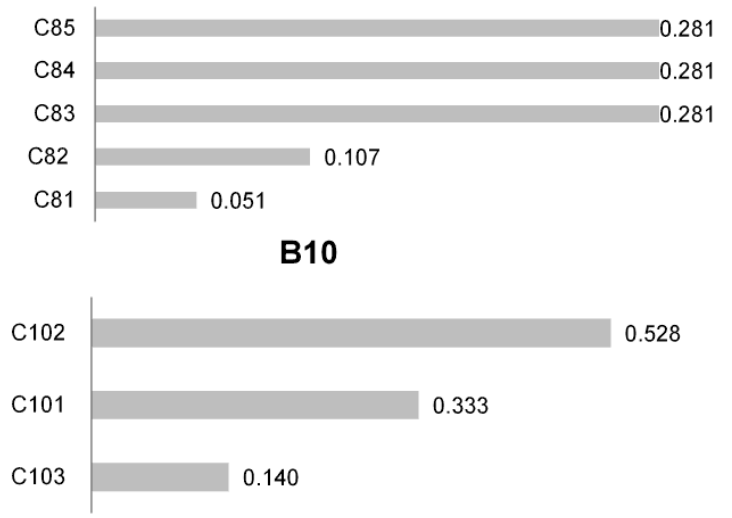

Fig.A.2 $w_{j}$ values achieved for the criteria of the second level in the ICT area and $w_{k}$ values achieved for the criteria of the third level in the B6, B7, B8, B9 and B10 clusters of subcriteria values for the consistency ratio of the matrix (CR) are shown. 
BI AREA

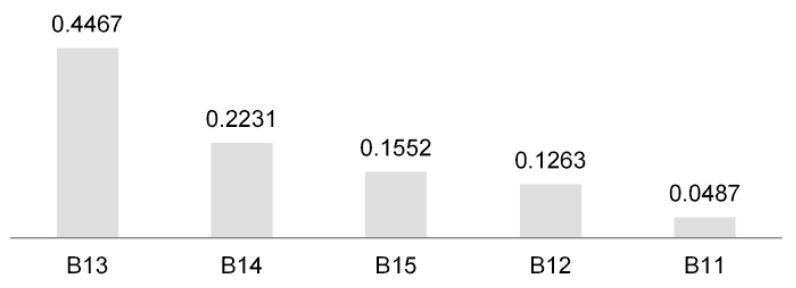

B13
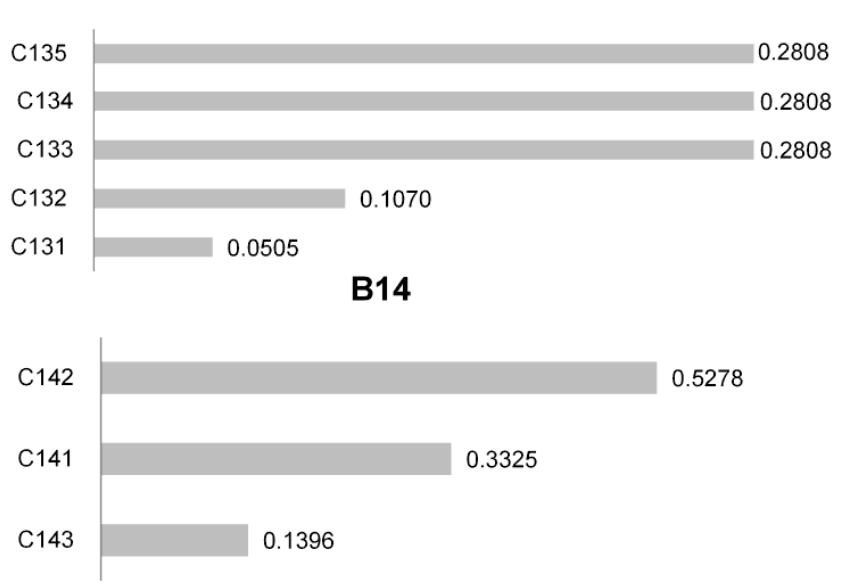

B11

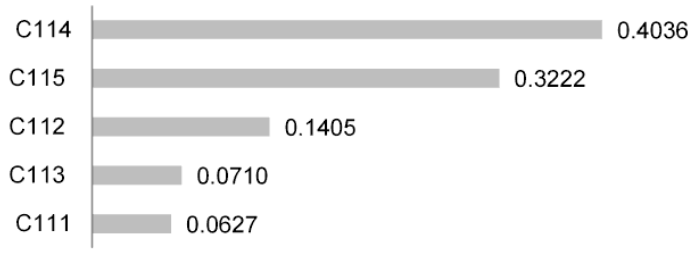

B12

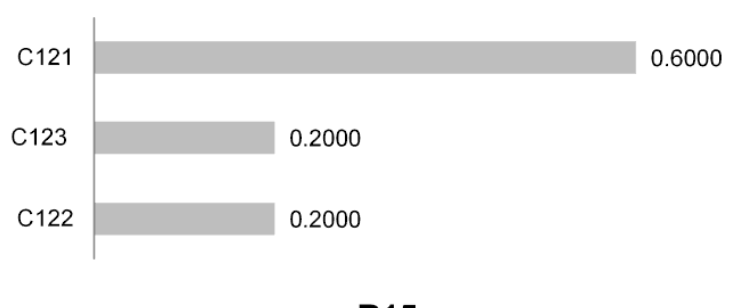

B15

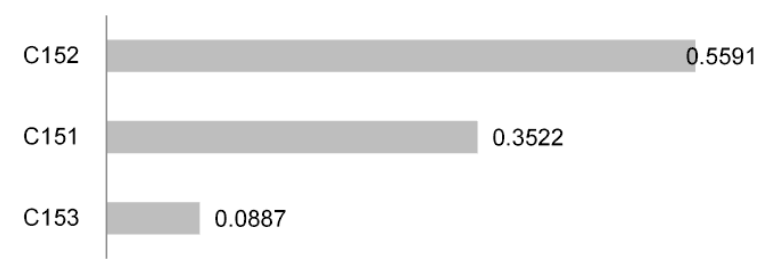

Fig.A.3 $w_{j}$ values achieved for the criteria of the second level in the $\mathrm{Bl}$ area and $\mathrm{w}_{\mathrm{k}}$ values achieved for the criteria of the third level in the B11, B12, B13, B14 and B15 clusters of subcriteria values for the consistency ratio of the matrix $(C R)$ are shown.

\section{SAFETY AND SECURITY AREA}

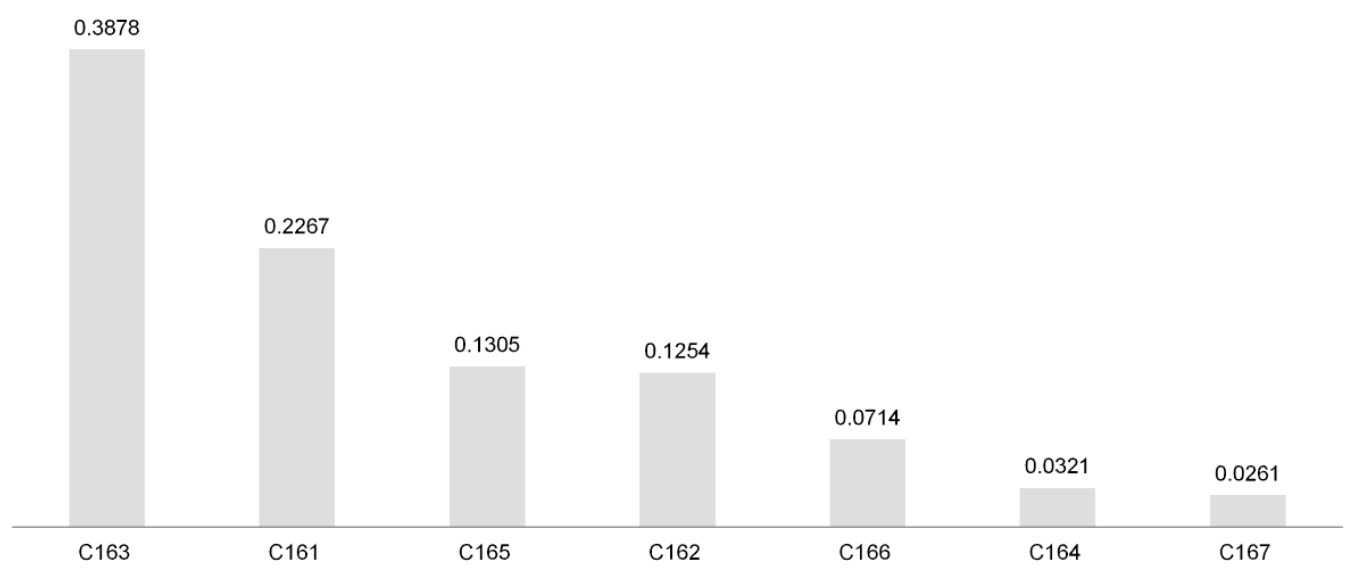

Fig.A.4 $w_{j}$ values achieved for criteria of the level in the Safety and Security area. 
ENVIRONMENT CARE AREA

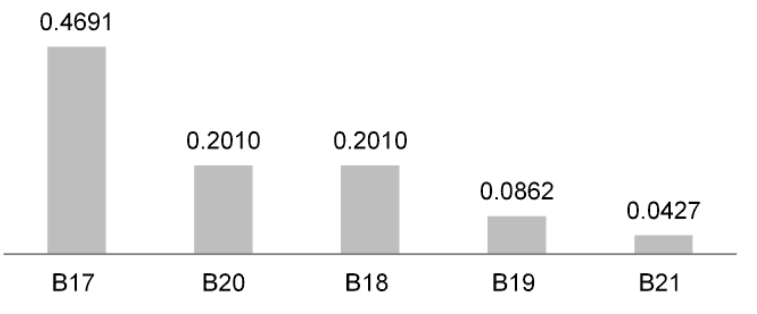

B18

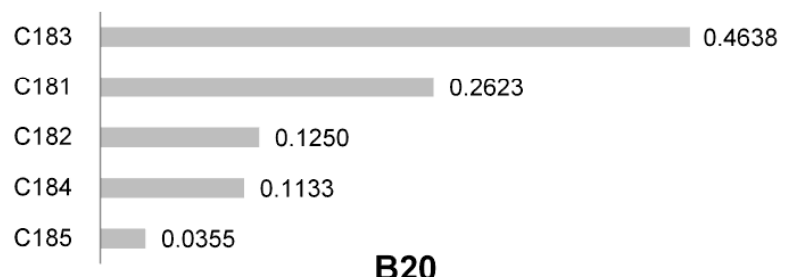

B20

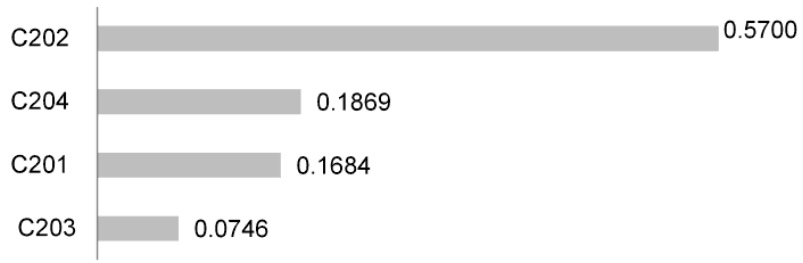

B17

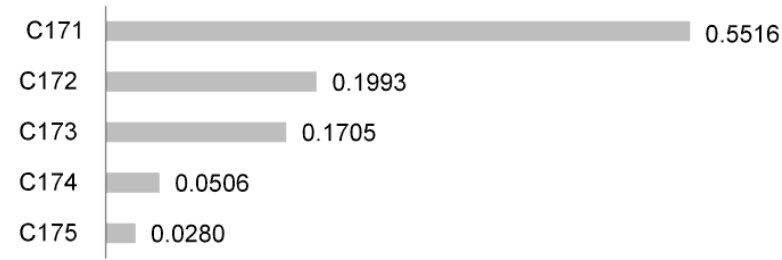

B19

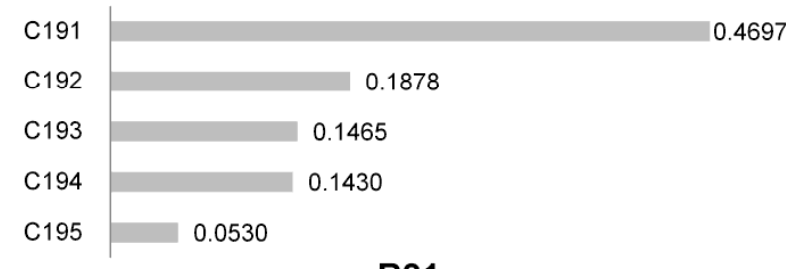

B21

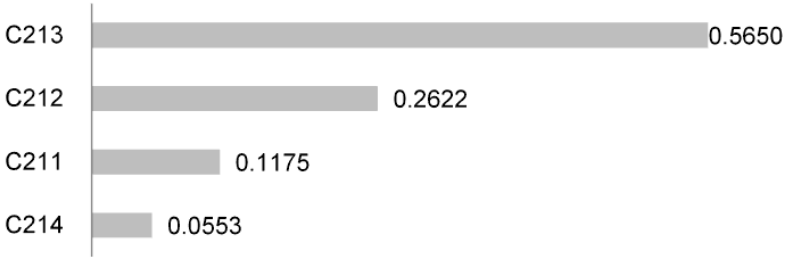

Fig.A.5 $w_{j}$ values achieved for the criteria of the second level in the Environment Care area and $\mathrm{W}_{\mathrm{k}}$ values achieved for the criteria of the third level in the B17, B18, B19, B20 and B21 clusters of subcriteria values for the consistency ratio of the matrix $(C R)$ are shown. 
Appendix B

\begin{tabular}{|c|c|c|c|c|c|c|}
\hline $\begin{array}{l}\text { Rank } \\
\text { position }\end{array}$ & $\begin{array}{l}W_{i} \\
\text { (all) } \\
=0.2\end{array}$ & $\begin{array}{l}\mathbf{w}_{\mathrm{i}} \\
\text { (Equipment) } \\
=0.3\end{array}$ & $\begin{array}{l}w_{i} \\
(I C T s) \\
=0.3\end{array}$ & $\begin{array}{l}W_{i} \\
(B I) \\
=0.3\end{array}$ & $\begin{array}{l}\mathrm{W}_{\mathrm{i}} \\
\text { (Safety } \\
\text { and } \\
\text { Security) } \\
=0.3\end{array}$ & $\begin{array}{l}\mathbf{w}_{\mathrm{i}} \\
\text { (Enviromnent } \\
\text { care) }=0.3\end{array}$ \\
\hline 1 & C163 & C12 & C163 & C12 & C163 & C171 \\
\hline 2 & C12 & C163 & C91 & C163 & C161 & C163 \\
\hline 3 & C171 & C171 & C92 & C171 & C12 & C12 \\
\hline 4 & C161 & C161 & C71 & C161 & C171 & C161 \\
\hline 5 & C142 & C142 & C12 & C142 & C142 & C142 \\
\hline 6 & C91 & C24 & C171 & C24 & C165 & C202 \\
\hline 7 & C92 & C11 & C161 & C11 & C162 & C91 \\
\hline 8 & C71 & C91 & C142 & C91 & C91 & C92 \\
\hline 9 & C121 & C92 & C121 & C92 & C92 & C71 \\
\hline 10 & C141 & C71 & C141 & C71 & C71 & C121 \\
\hline 11 & C165 & C121 & C165 & C121 & C121 & C172 \\
\hline 12 & C162 & C14 & C162 & C14 & C141 & C183 \\
\hline 13 & C24 & C141 & C24 & C141 & C166 & C141 \\
\hline 14 & C202 & C165 & C202 & C165 & C24 & C173 \\
\hline 15 & C11 & C162 & C11 & C162 & C202 & C165 \\
\hline 16 & C172 & C41 & C102 & C41 & C11 & C162 \\
\hline 17 & C183 & C202 & C93 & C202 & C172 & $\mathrm{C} 24$ \\
\hline 18 & C14 & C52 & C72 & C52 & C183 & C11 \\
\hline 19 & C173 & C53 & C73 & C53 & C14 & C181 \\
\hline 20 & C166 & C172 & C172 & C172 & C173 & C14 \\
\hline
\end{tabular}




\begin{tabular}{|c|c|c|c|c|c|c|}
\hline 21 & $\mathrm{C} 41$ & $\mathrm{C} 183$ & $\mathrm{C} 183$ & $\mathrm{C} 183$ & $\mathrm{C} 41$ & $\mathrm{C} 166$ \\
\hline 22 & $\mathrm{C} 152$ & $\mathrm{C} 173$ & $\mathrm{C} 14$ & $\mathrm{C} 173$ & $\mathrm{C} 152$ & $\mathrm{C} 191$ \\
\hline 23 & $\mathrm{C} 52$ & $\mathrm{C} 13$ & $\mathrm{C} 173$ & $\mathrm{C} 13$ & $\mathrm{C} 52$ & $\mathrm{C} 41$ \\
\hline 24 & $\mathrm{C} 53$ & $\mathrm{C} 166$ & $\mathrm{C} 166$ & $\mathrm{C} 166$ & $\mathrm{C} 53$ & $\mathrm{C} 152$ \\
\hline 25 & $\mathrm{C} 102$ & $\mathrm{C} 152$ & $\mathrm{C} 101$ & $\mathrm{C} 152$ & $\mathrm{C} 102$ & $\mathrm{C} 52$ \\
\hline 26 & $\mathrm{C} 93$ & $\mathrm{C} 102$ & $\mathrm{C} 41$ & $\mathrm{C} 102$ & $\mathrm{C} 93$ & $\mathrm{C} 53$ \\
\hline 27 & $\mathrm{C} 143$ & $\mathrm{C} 93$ & $\mathrm{C} 152$ & $\mathrm{C} 93$ & $\mathrm{C} 143$ & $\mathrm{C} 204$ \\
\hline 28 & $\mathrm{C} 72$ & $\mathrm{C} 143$ & $\mathrm{C} 52$ & $\mathrm{C} 143$ & $\mathrm{C} 72$ & $\mathrm{C} 102$ \\
\hline 29 & $\mathrm{C} 73$ & $\mathrm{C} 72$ & $\mathrm{C} 53$ & $\mathrm{C} 72$ & $\mathrm{C} 73$ & $\mathrm{C} 93$ \\
\hline 30 & $\mathrm{C} 122$ & $\mathrm{C} 73$ & $\mathrm{C} 143$ & $\mathrm{C} 73$ & $\mathrm{C} 122$ & $\mathrm{C} 143$ \\
\hline
\end{tabular}

Table B.1. Rank of priorities of the most relevant criteria of the third-level analysis when increasing the values of $\mathrm{w}_{\mathrm{i}}$ of the main areas of Equipment, ICTs, BI, Safety and Security and Environment care. 